\title{
East-west differentiation in the Marcusenius macrolepidotus species complex in Southern Africa: the description of a new species for the lower Cunene River, Namibia (Teleostei: Mormyridae)
}

\author{
Bernd Kramer $^{\mathrm{a} *}$ and Michael Wink ${ }^{\mathrm{b}}$ \\ ${ }^{a}$ University of Regensburg, Zoological Institute, Universitätsstrasse 31, D-93040 Regensburg, \\ Germany; ${ }^{b}$ Heidelberg University, Institute of Pharmacy and Molecular Biotechnology, Im \\ Neuenheimer Feld 364, D-69120 Heidelberg, Germany
}

(Received 3 April 2012; final version received 15 April 2013; first published online 18 July 2013)

\begin{abstract}
This paper critically compares the Southern African bulldog fish species Marcusenius macrolepidotus (Peters, 1852), inhabiting the eastern Lower Zambezi River, and Marcusenius altisambesi Kramer et al., 2007, inhabiting the central Upper Zambezi River, with bulldog fish samples from the western lower Cunene River, a $2600-\mathrm{km}$ range from the Indian Ocean to the Atlantic. The three species or forms are well differentiated in morphology and molecular genetics, and differentiation is also present in electric organ discharges. Marcusenius altisambesi and the Cunene sample, which we recognize as Marcusenius multisquamatus sp. nov., are closely related and form a sister taxon to M. macrolepidotus. This result is based on the analysis of mitochondrial cytochrome $b$ sequences and genomic Inter-simple-sequence-repeat fingerprinting. Morphological adaptations to life in a torrential escarpment river seem to be present in M. multisquamatus sp. nov. when compared with $M$. altisambesi, which lives in a reservoir river that periodically floods the savannah.
\end{abstract}

http://www.zoobank.org/urn:lsid:zoobank.org:pub:8FE68494-9ED9-428E-B181E814D25493F2

Keywords: systematics; morphometrics; electric organ discharges; molecular genetics; allopatric speciation

\section{Introduction}

The name-giving genus of the largest freshwater fish family endemic to Africa, the Mormyridae, has been known from the time of Linnaeus (Mormyrus Linnaeus, 1758). A major systematic revision and phylogeny of the family was given by Taverne (1971b; 1972). Since then, many new species have been described from West Africa (Bigorne 2003) and Lower Guinea in West-Central Africa (Hopkins et al. 2007). Together with Central Africa, these ichthyological provinces are the most species-rich for mormyrids, with several to many species per genus. This is in contrast to southern Africa, where there were traditionally only one or two wide-ranging species per genus (eight species in all, Skelton 1993). In the meantime, several new species have also been described from southern and eastern Africa.

*Corresponding author. Email: bernd.kramer@biologie.uni-regensburg.de

This article was originally published with errors. This version has been corrected. Please see Corrigendum (http://dx.doi.org/10.1080/00222933.2013.853913). 
For example, the geographical range of Marcusenius macrolepidotus (Peters, 1852), commonly referred to as the bulldog fish, used to be so huge it included the rivers and lakes of most of southern Africa, East Africa, and the upper Congo (Skelton 2001). A recent revision of $M$. macrolepidotus for its southern and eastern African range concluded that there were at least five species rather than a single one (Kramer et al. 2007). Two of these are resurrected species, namely Marcusenius angolensis (Boulenger, 1905) for the Angolan Quanza River, and Marcusenius pongolensis (Fowler, 1934) for South Africa's east coast rivers draining into the Indian Ocean, which had previously been synonymized with $M$. macrolepidotus. Two are new species, one for Kenya (Marcusenius devosi Kramer et al., 2007), and one for the Upper Zambezi-Okavango system (Marcusenius altisambesi Kramer et al., 2007).

The assumed eastern range limit of M. altisambesi is the Victoria Falls, as has been observed for many other Upper Zambezian fish species (Jubb 1958; Balon 1974; Skelton 2001). It is not yet clear whether or not a recent observation of a few specimens below the Falls (Minshull 2010) is a regular phenomenon (J. Minshull, personal communication). Marcusenius altisambesi's western range includes the Okavango delta, but nothing is known further west; in particular, the major and independent Cunene River has not been explored (Figure 1). Like the headwaters of the Okavango, the Cunene arises in the Angolan highlands of Bié, and flows southward in parallel and close to the upper Cubango (the western headwaters of the Okavango). Whereas the Cubango takes a southeasterly course to its inland delta in Botswana, the Cunene turns sharply westward (at Olushandja) and forms the Angolan/Namibian border for the last $300 \mathrm{~km}$ of its $945-\mathrm{km}$ course, to discharge into the Atlantic.

Only weak differentiation has been found between bulldog fish from the Upper Zambezi compared with those from the Okavango, regarded as infra-subspecific and within the limits of the new species M. altisambesi (Kramer et al. 2007). Such geographical variability may result from limited gene flow between the two systems, which are sporadically linked via the Selinda spillway and the Kwando River.

A similar situation may hold for the comparison of bulldog fish from the Cunene River and the Upper Zambezi system (including the Okavango). These populations appear isolated from each other, but a high Similarity Index between fish populations in the two river systems points to a former linkage (Skelton 1994). In fact, a former linkage of the Cunene River with the Cubango River via the ephemeral Colui, which forms the eastern headwaters of the Cunene, has been proposed (Moore and Larkin 2001, p. 66). Therefore, a measure of (perhaps increased) geographic variation but within the definition of $M$. altisambesi may be expected for the Cunene bulldog fish. However, a seemingly high Similarity Index may also arise from insufficient knowledge of the fish species concerned, because in mormyrids, critical comparisons of allopatric populations did not include those from the Cunene. The present study tries to determine the systematic status of the Cunene bulldog fish.

\section{Material and methods}

\section{Morphological and electrical studies}

A total of 26 bulldog fish specimens from the Cunene River's lower course were studied (from where it forms the Namibian/Angolan border: localities nos 8, 9 and 10 of Figure 1). This section of the Cunene River crosses the escarpment that faces the Atlantic Ocean. Location 9 is just above the Epupa Falls, location 8 just below the Ruacana Falls (at $600 \mathrm{~m}$ and $800 \mathrm{~m}$ altitude above sea level, respectively; 15 


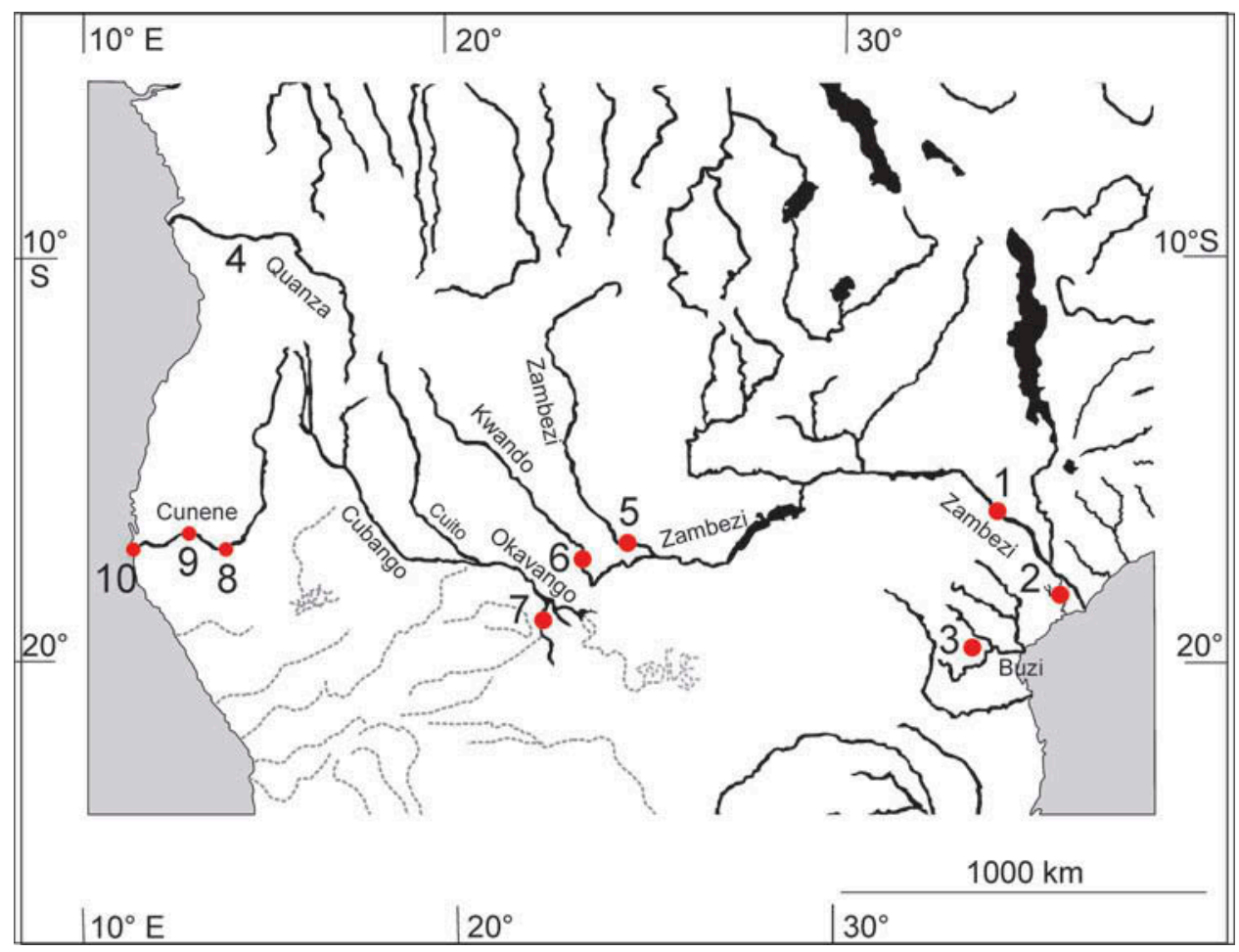

Figure 1. Map of sampling locations in southern Africa. (A) Type locality for Marcusenius macrolepidotus (Peters, 1852), Tete on the Lower Zambezi River; (B) origin of M. macrolepidotus, SAIAB 60847, from Marromeu, Lower Zambezi delta (Figure 4A); (C) origin of M. macrolepidotus from the Buzi System, same location as SAIAB 67369, presently alive in aquarium; (D) likely type region for Marcusenius angolensis (Boulenger, 1905), the Lower Quanza; (E) Marcusenius altisambesi Kramer et al., 2007, type locality on the Upper Zambezi River; (F) M. altisambesi from the Kwando River; (G) M. altisambesi from the Okavango delta; (H, I) Marcusenius multisquamatus sp. nov., stretching from below the Ruacana Falls to above the Epupa Falls (I), the type locality; (J) specimens from the Cunene River Mouth.

“escarpment specimens"). The 11 specimens from location 10 at the river mouth were sampled just above sea level. These 26 specimens were compared with 202 specimens from the Okavango/Zambezi systems. At least 13 measurements (see Figure 2) and four counts were taken on morphological characters. The following abbreviations were used: PDL, predorsal length: distance from tip of snout (excluding mental lobe or chin) to dorsal fin origin; PAL, preanal length: distance from tip of snout to anal fin origin; $\mathrm{LD}$, dorsal fin length; LA, anal fin length; $\mathrm{pD}$, distance from dorsal fin origin to end of caudal peduncle; CPL, length of caudal peduncle (end of anal fin base to midbase of caudal fin); CPD, depth of caudal peduncle: the least vertical distance across the caudal peduncle; LS, length of snout: distance from tip of snout to posterior orbital rim of eye (LSo) or centre of eye (LSc); HL, head length: distance from tip of the snout to furthest bony edge of the operculum; $\mathrm{Na}$, distance between the pair of nares of one side (from centre to centre); OD, eye diameter: defined by orbital rims; LPF, length of pectoral fins; PPF, distance between anterior base of pectoral fin to anterior base of pelvic fin; SL, standard length: distance from tip of snout to midbase of caudal fin; BD, body depth: the greatest vertical distance across the body; TL, total length: 

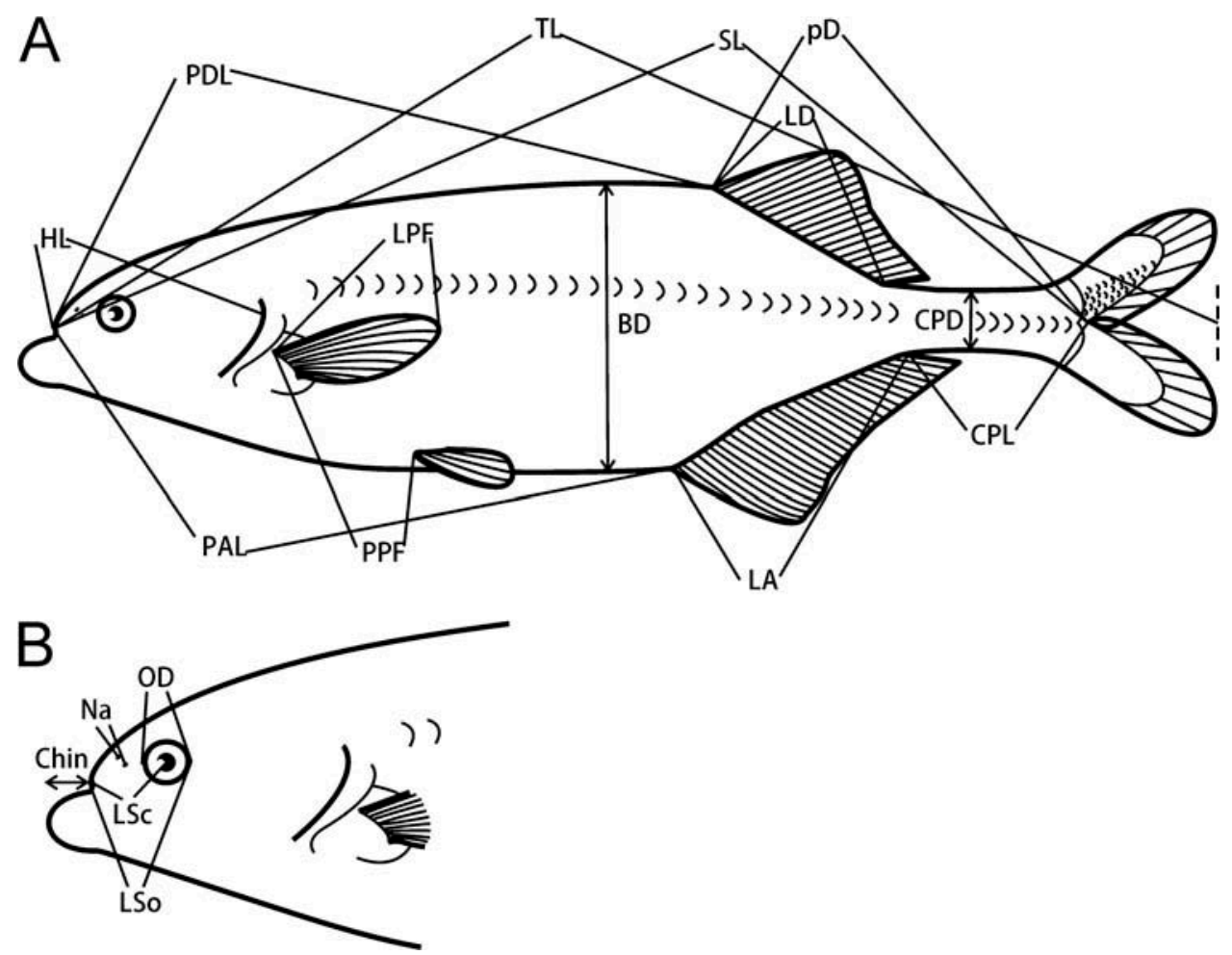

Figure 2. Morphological measures used in the present study (A), detail of head (B). For explanation of abbreviations, see Material and methods.

distance from tip of snout to end of caudal fin; CL, mental lobe or chin length; nD, number of dorsal fin rays; nA, number of anal fin rays; SPc, number of scales around caudal peduncle; SLS, number of scales in linear series along the lateral line row, as detailed in Skelton (2001: 67); SLS range of accuracy, \pm 2 counts.

Abbreviations used to represent institutions and collections cited follow Leviton et al. (1985) and Fricke and Eschmeyer (2012). Collection acronyms used in the present paper were: BMNH, Natural History Museum, London, UK; IPBM, Institute of Pharmacy and Molecular Biotechnology, Heidelberg University, Germany; USNM, Smithsonian Institution National Museum of Natural History, Washington D.C., USA; SAIAB, South African Institute for Aquatic Biodiversity, Grahamstown, South Africa; ZSM, Zoologische Staatssammlung München, Germany. Specimens examined were identified using dichotomous keys in Bell-Cross and Minshull (1988) and Skelton (1993; 2001), which are considered effective for fish populations occurring in southern Africa.

Electric organ discharges (EODs) of 157 fish were recorded in the field (exceptions given below) immediately after capture in a 37-litre plastic aquarium filled with river water from where the fish was collected. Conductivity changes possibly affecting EOD were excluded. Fish from the Buzi River and Upper Zambezi River (batch caught on 21 August 1999) were recorded in the European laboratory, following an acclimatization period of at least 2 weeks after air transport.

Temperature $\left( \pm 0.1^{\circ} \mathrm{C}\right)$ and water conductivity $\left( \pm 1 \mu \mathrm{S} \mathrm{cm}{ }^{-1}\right)$ were constantly monitored using an electronic apparatus (LF92 by Wissenschaftlich-Technische 
Werkstätten, WTW, Germany). Fish were placed between a pair of carbon rod electrodes that were connected to a differential amplifier with a variable gain (up to $\times 10$; $0.2 \mathrm{~Hz}$ to $100 \mathrm{kHz}$; filter slopes, $-3 \mathrm{~dB}$ per octave; electronics workshop, Biology Department, University of Regensburg). Amplifier output was recorded with a digital storage oscilloscope (up to at least $10 \mathrm{MHz}$ conversion rate, amplitude resolution 8 bit, 512 points per trace in the field, replaced by a $100 \mathrm{MHz} / 9 \mathrm{bit} / 10,000$ points per sweep oscilloscope from 2003 on; $150 \mathrm{MHz} / 13 \mathrm{bit} / 5000$ points in the laboratory), and data were numerically transferred onto the hard disc of a computer via digital interface. Usually eight traces per fish were recorded. Field equipment was battery-operated.

Custom-designed computer programs were used for analysis of EODs (programmed using a software package for signal analysis, FAMOS v3.1 to v6.2). When necessary, EOD duration was corrected to $25^{\circ} \mathrm{C}$ using a $\mathrm{Q}_{10}$ value of 1.5 (Kramer and Westby 1985) before data analysis.

Definition of EOD waveform variables (compare with Figure 3): P1amp, peak amplitude of positive P1 phase (i.e. from baseline to peak, which was set equal to 1 by definition); Namp, peak amplitude of negative $\mathrm{N}$ phase of EOD re: P1amp = 1; P1dur, Ndur, durations of $\mathrm{P} 1$ phase and $\mathrm{N}$ phase; P1Nsep, separation (or interval) between the peaks of the P1 and N phases; P1area, Narea, areas under the P1 and N phases. Durations in microseconds; amplitudes in relative Volts (re: P1-phase amplitude $=1$ ). Area measures, dimension $(V \times$ microseconds). Because of the asymptotic start and termination of an EOD, P1dur started at $+5 \%$ of P1amp, and Ndur ended at $-5 \%$ of Plamp. This threshold criterion was also used for Plarea and Narea estimations.

Subsequent to EOD recording, fish were either killed by an overdose of the anaesthetic 2-phenoxy-ethanol, the standard length (SL) determined using vernier callipers and the fish fixed in $10 \%$ formalin for morphological studies; or the fish were transported live to the South African Institute for Aquatic Biodiversity (SAIAB) at Grahamstown or the University of Johannesburg, by road (with the water permanently oxygenated by a battery-powered air bubbler). (The 11 specimens from the Cunene River mouth were fixed in $96 \%$ ethanol, and EOD recordings had not been taken.) After a recovery period of 3-5 days in the aquaria of SAIAB or the University of Johannesburg, fish were put on an overnight flight direct to Germany. They were packed using medical oxygen-inflated plastic bags and temperature-insulated boxes from the aquarium trade. Fish were sexed using the kink criterion of the anal fin base (kink absent in females).

Principal component analysis on correlations among anatomical characters were used to test differences in body shape among populations because it does not require a priori assumptions about taxonomic groups. Analyses of variance were performed to test hypotheses of no difference between samples for each character individually. Multivariate analyses of variance were performed so as not to overestimate differentiation when examining the hypothesis of no morphological difference between fish from different origins by inferential statistics (McGarigal et al. 2000). Values of $p$ are two-tailed unless otherwise stated. For interpreting the principal components in terms of the anatomical characters, we determined the component loadings, i.e. the principal component structure (see McGarigal et al. 2000). For assessing the significance of component loadings we followed Tabachnick and Fidell (2007). These authors recognize five levels of significance: loadings $>0.32$ or $<-0.32$ are poor, $>0.45$ or $<-0.45$ fair, $>0.55$ or $<-0.55$ good, $>0.63$ or $<-0.63$ very good, and $>0.71$ or $<-0.71$ excellent. These benchmarks account for 10\%, 20\%, 30\%, 40\% and 50\% of the variance in the component, respectively. The software used was JMP v9 (SAS Institute, 2003-2010). 


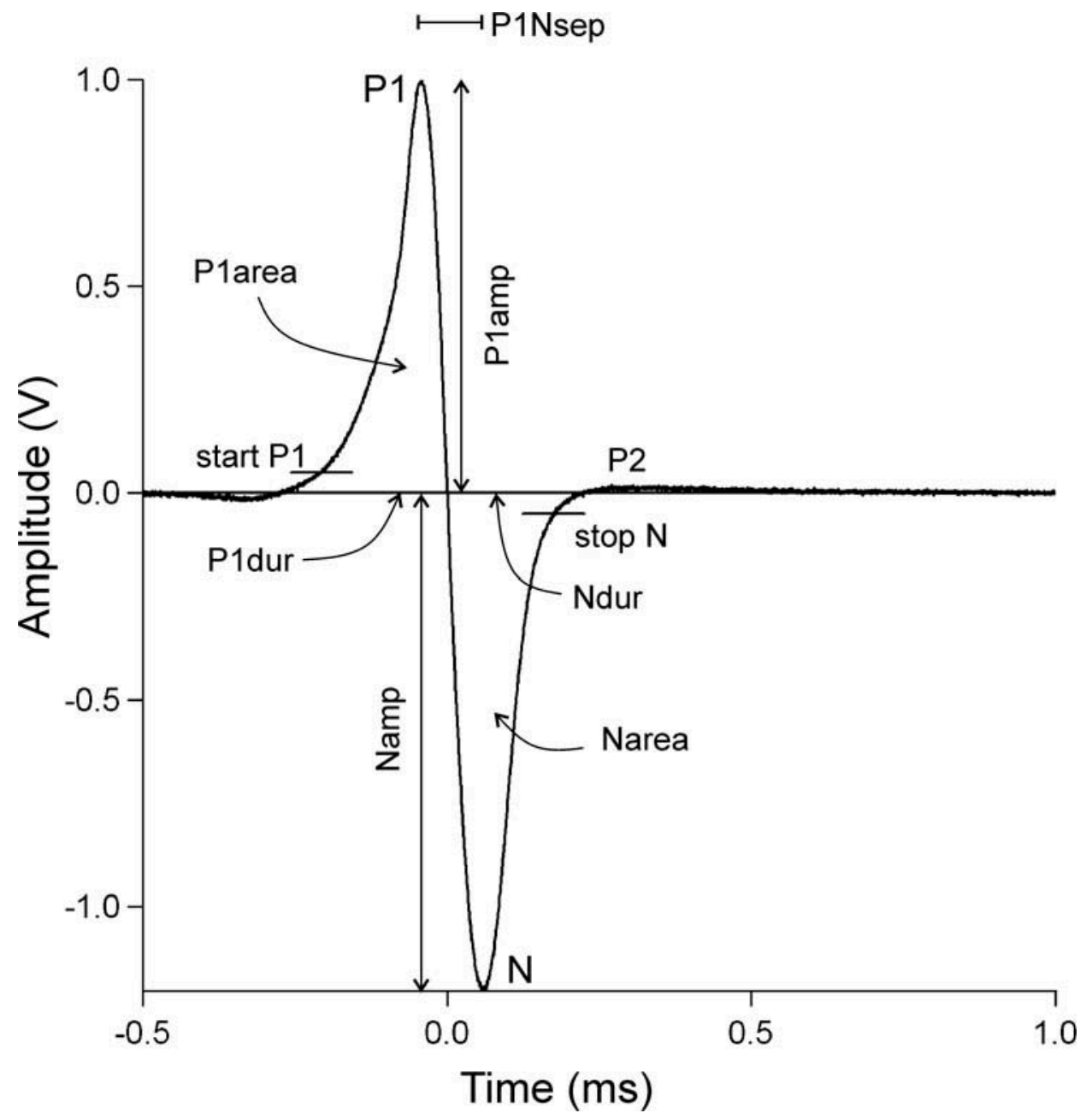

Figure 3. A bulldog fish Electric organ discharge (EOD), centred on the zero-crossing of the main transient, with baseline superimposed. The variables as used in the present study and how they were defined. The beginning of an EOD was defined by "start P1", at $5 \%$ of the absolute value of the amplitude of the P1 peak (or P1amp, which was 1 by definition). P1dur(ation) ended at time $=0 \mathrm{~ms}$ where the $\mathrm{N}$ phase started. An EOD (as well as Ndur) ended where the ascending slope of the $\mathrm{N}$ phase crossed the $-5 \%$ threshold ("stop N"). This stop criterion was chosen because an appreciable $\mathrm{P} 2$ phase was not present in all specimens. P1Nsep, the interval between $\mathrm{P} 1$ peak and negative $\mathrm{N}$ peak. P1area, Narea, the areas under the P1 and $\mathrm{N}$ peaks, respectively. EOD shown was recorded from an Marcusenius multisquamatus sp. nov. sampled from Cunene/Epupa Falls.

\section{Genetic studies}

\section{DNA isolation, PCR and sequencing}

DNA was isolated from ethanol-preserved tissues or scales using standard procedures as described previously (Kramer et al. 2007). The mitochondrial cytochrome $b$ gene 
(between 750 and 960 base pairs) was amplified by polymerase chain reaction (PCR) and sequenced as in previous publications (Kramer et al. 2007).

Sequences were aligned using CLUSTALX and corrected manually. The aligned sequences were analysed by MEGA5 (Tamura et al. 2011). Maximum likelihood was used to reconstruct the phylogeny. Conditions: Substitution Model: General Time Reversible model; rates among sites: gamma-distributed with invariant sites $(G+\mathrm{I})$ and five discrete gamma categories. Tree inference options: maximum likelihood heuristic method: Nearest-Neighbour Interchange. All codons were included. Phylogeny Test: Bootstrap method with 1000 replications. The closely related mormyrids Hippopotamyrus szaboi (KC202214, KC202215) and Pollimyrus cf. marianne (KC202216, KC202217), which we had studied previously (Kramer et al. 2003, 2004) were used as outgroups.

\section{ISSR genomic fingerprinting}

Total DNA of $M$. altisambesi, M. multisquamatus sp. nov. and M. macrolepidotus was amplified using the Inter-simple-sequence-repeat (ISSR) primer MW4 (GACA) 4 . The PCR products were separated by high-resolution polyacrylamide gel electrophoresis as described earlier (Kramer et al. 2007).

\section{Systematics}

Genus Marcusenius Gill, 1862

\section{Diagnosis (translation of Taverne 1971a:106)}

Body moderately elongated; snout rather low, shorter than postorbital segment of the skull and chin with mental swelling; caudal peduncle 2 to 5 times longer than deep; dorsal fin with 19 to 36 rays; anal fin with 25 to 43 rays; pectoral fin with 10 to 12 rays; 38 to 98 scales in lateral series; 8 to $26 / 12$ to 28 in transversal line at the level of the body; 7 to $21 / 7$ to 21 scales in transversal line between dorsal and anal fins; 8 to 18 scales around caudal peduncle; 3 to $8 / 3$ to 10 conical or bicuspid teeth; lateral ethmoid present and well developed; mesethmoid small and straight; 5 circumorbital bones; pre-orbital and first infraorbital fused; 5 hypural bones; 42 to 49 vertebrae. Taverne (1971b) also gives a diagnosis including more detail on skeletal characters and a phylogeny (Taverne 1972) that, for the purpose of the present paper, can be summarized briefly as follows: the genus Marcusenius Gill 1862 sensu stricto, that is, in Taverne's definition that is valid at present, shares a lateral ethmoid with four other mormyrid genera, it shares five rather than six circumorbital bones with two of these other genera, but it does not share a reduced upper jaw with any of these (Taverne 1971b; 1972).

\section{Type species}

Marcusenius cyprinoides (Linnaeus, 1758)

Included species (from Eschmeyer 2013). Valid unless stated otherwise. 
abadii, Gnathonemus Boulenger, 1901. Current status: Valid as Marcusenius abadii

(Boulenger, 1901).

altisambesi, Marcusenius Kramer, Skelton, Van der Bank and Wink, 2007.

angolensis, Gnathonemus Boulenger, 1905. Current status: Valid as Marcusenius angolensis (Boulenger, 1905).

annamariae, Gnathonemus Parenzan, 1939. Current status: Valid as Marcusenius annamariae (Parenzan, 1939).

bentleyi, Mormyrus Boulenger, 1897. Current status: Valid as Marcusenius bentleyi

(Boulenger, 1897).

brucii, Gnathonemus Boulenger, 1910. Current status: Valid as Marcusenius brucii

(Boulenger, 1910).

cuangoanus, Gnathonemus Poll, 1967. Current status: Valid as Marcusenius cuangoanus (Poll, 1967).

cyprinoides, Mormyrus Linnaeus, 1758. Current status: Valid as Marcusenius cyprinoides (Linnaeus, 1758).

deboensis, Gnathonemus Daget, 1954. Current status: Valid as Marcusenius deboensis (Daget, 1954).

devosi, Marcusenius Kramer, Skelton, Van der Bank and Wink, 2007.

dundoensis, Gnathonemus Poll, 1967. Current status: Valid as Marcusenius dundoensis (Poll, 1967).

friteli, Gnathonemus Pellegrin, 1904. Current status: Valid as Marcusenius friteli (Pellegrin, 1904).

furcidens, Gnathonemus Pellegrin, 1920. Current status: Valid as Marcusenius furcidens (Pellegrin, 1920).

fuscus, Gnathonemus Pellegrin, 1901. Current status: Valid as Marcusenius fuscus (Pellegrin, 1901).

ghesquierei, Gnathonemus Poll, 1945. Current status: Valid as Marcusenius ghesquierei (Poll, 1945).

gracilis, Marcusenius Kramer, 2013.

greshoffi, Mormyrus Schilthuis, 1891. Current status: Valid as Marcusenius greshoffii

(Schilthuis, 1891).

intermedius, Marcusenius Pellegrin, 1924.

kainji, Marcusenius Lewis, 1974. Uncertain status as Marcusenius kainji Lewis, 1974.

Current status: Marcusenius kainji Lewis, 1974.

kutuensis, Gnathonemus Boulenger, 1899. Current status: Valid as Marcusenius kutuensis (Boulenger, 1899).

leopoldianus, Gnathonemus Boulenger, 1899. Current status: Valid as Marcusenius leopoldianus (Boulenger, 1899).

livingstonii, Gnathonemus Boulenger, 1899. Current status: Valid as Marcusenius livingstonii (Boulenger, 1899).

multisquamatus, Marcusenius Kramer and Wink, 2013.

macrolepidotus, Mormyrus Peters, 1852. Current status: Valid as Marcusenius macrolepidotus (Peters, 1852).

macrophthalmus, Gnathonemus Pellegrin, 1924. Current status: Valid as Marcusenius macrophthalmus (Pellegrin, 1924).

mento, Mormyrus Boulenger, 1890. Current status: Valid as Marcusenius mento

(Boulenger, 1890).

meronai, Marcusenius Bigorne and Paugy, 1990. 
monteiri, Mormyrus Günther, 1873. Current status: Valid as Marcusenius monteiri (Günther, 1873).

moorii, Mormyrus Günther, 1867. Current status: Valid as Marcusenius moorii (Günther, 1867).

ntemensis, Gnathonemus Pellegrin, 1927. Current status: Valid as Marcusenius ntemensis (Pellegrin, 1927).

pongolensis, Gnathonemus Fowler, 1934. Current status: Valid as Marcusenius pongolensis (Fowler, 1934).

sanagaensis, Marcusenius Boden, Teugels and Hopkins, 1997.

schilthuisiae, Gnathonemus Boulenger, 1899. Current status: Valid as Marcusenius schilthuisiae (Boulenger, 1899).

senegalensis, Mormyrus Steindachner, 1870. Current status: Valid as Marcusenius senegalensis (Steindachner, 1870).

stanleyanus, Mormyrus Boulenger, 1897. Current status: Valid as Marcusenius stanleyanus (Boulenger, 1897).

thomasi, Gnathonemus Boulenger, 1916. Current status: Valid as Marcusenius thomasi (Boulenger, 1916).

ussheri, Mormyrus Günther, 1867. Current status: Valid as Marcusenius ussheri (Günther, 1867).

victoriae, Gnathonemus Worthington, 1929. Current status: Valid as Marcusenius victoriae (Worthington, 1929). [37 spp].

Marcusenius altisambesi Kramer et al., 2007

(Figure 4C, D)

Gnathonemus okavangensis Pappenheim, 1907. "Appeared as a form of Gnathonemus macrolepidotus Peters from the Okavango R., Damaraland, Africa; regarded as infrasubspecific and not available" (Eschmeyer 2013). "Nomen dubium" according to Gosse (1984) and Seegers (1996, p. 73).

Gnathonemus macrolepidotus: Gilchrist and Thompson 1913, pp. 330-331.

Marcusenius altisambesi Kramer et al. (2007), pp. 681-684.

Type specimens

Holotype: SAIAB 79135 (specimen L39isi), Namibia: Caprivi Strip: Lisikili on Upper Zambezi River. Paratypes: SAIAB 79136 (6), SAIAB 79137 (3), ZSM 35086 (5), ZSM 35085 (2), ZSM 35097 (1), ZSM 35082 (2); all examined.

- Non-types, examined. One hundred and four specimens from the Upper Zambezi River System, East Caprivi, Namibia, some specimens from Kalimbeza presently alive in Aquarium:

- SMF 28264 (22 specimens), from the Zambezi River, Lisikili backwater, $17^{\circ} 33^{\prime} \mathrm{S}, 2^{\circ} 29^{\prime}$ E (type locality), coll.: F.H. van der Bank and B. Kramer, 5-7 March 1994,

- SMF 28264 (45 specimens), ZSM 35084 (1), from the Kwando River, Nakatwa, $18^{\circ} 06^{\prime} \mathrm{S}, 23^{\circ} 23^{\prime} \mathrm{E}$, in Mudumu National Park, coll.: B. Kramer, 9-15 March 1994, locality 6 on Figure 1, 


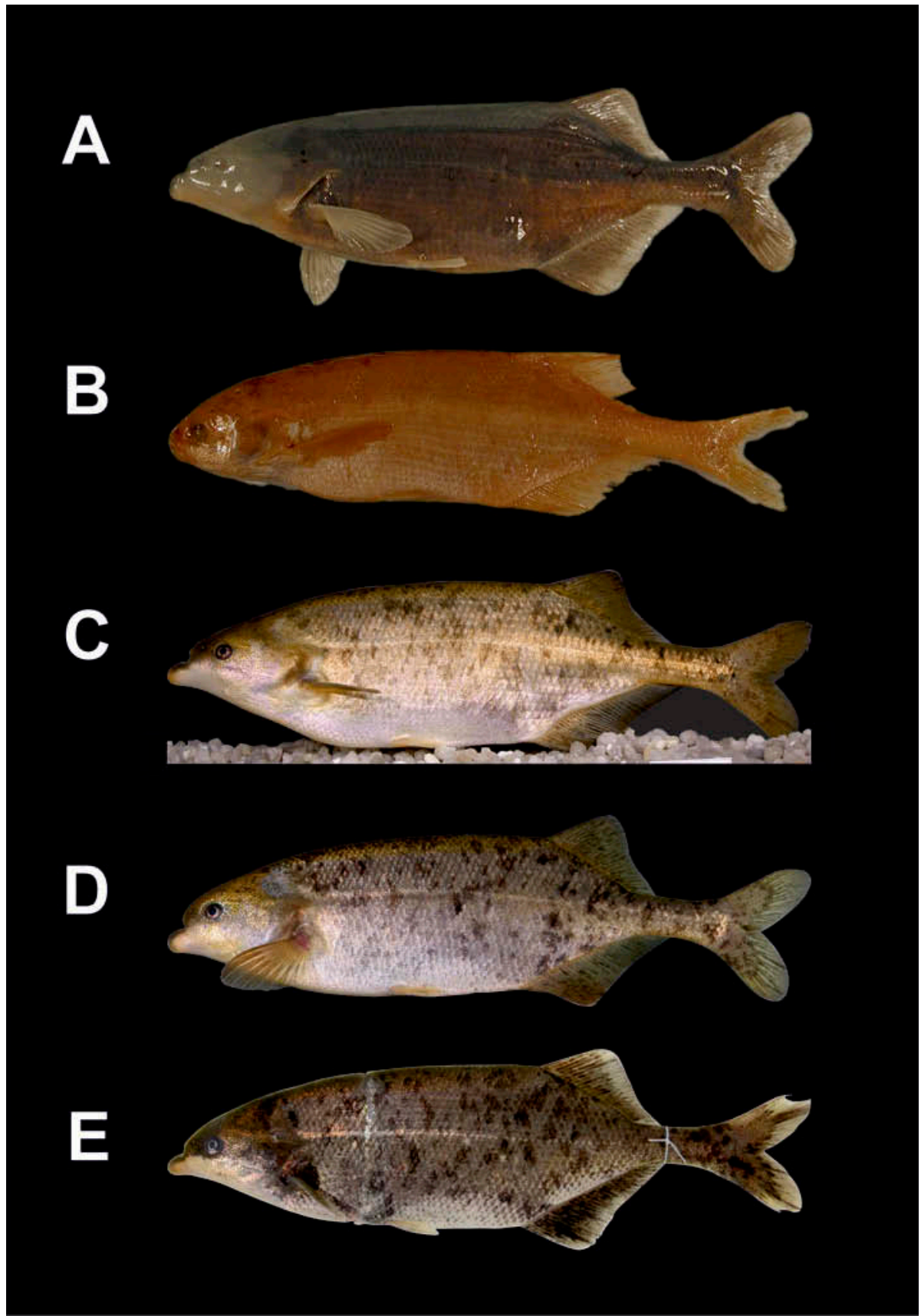

Figure 4. Photographs of bulldog fish from various origins. (A) Marcusenius macrolepidotus (Peters, 1852), SAIAB 60847, coll. R. Bills 1 August 1999, Lower Zambezi; (B) Marcusenius angolensis (Boulenger, 1905), BMNH 1905.5.29.64 (holotype); (C) Marcusenius altisambesi, coll. F. H. van der Bank and B. Kramer, 21 August 1999, Upper Zambezi, Kalimbeza, live specimen of $16.5 \mathrm{~cm}$ SL photographed 3 July 2003 in aquarium; (D) M. altisambesi, coll. F.H. van der Bank and B. Kramer, 11/12 August 2004, Okavango River, live fish of SL $13 \mathrm{~cm}$ photographed 20 April 2006 in aquarium; (E) Marcusenius multisquamatus sp. nov., coll. B. Kramer and Ernst Swartz, coll. and photographed on 19 August 2006, Cunene River, below Ruacana Falls, specimen RUAC01, SL $15.4 \mathrm{~cm}$. 
- SMF 28264 (two specimens), from Kwando River, Nkasa Island (18 27’ S, $23^{\circ} 42^{\prime}$ E) in Mamili National Park, close to locality 6 on Figure 1, coll.: F.H. van der Bank and B. Kramer, 9-10 September 1993,

- 31 specimens, about $500 \mathrm{~m}$ from opposite Kalimbeza fishing camp, at downstream tip of small island between Lisikili side channel and main channel, coll.: F.H. van der Bank and B. Kramer, caught 21 August 1999, water conductivity and temperature, $84 \mu \mathrm{S} \mathrm{cm}^{-1}, 22{ }^{\circ} \mathrm{C}$, size range $7.2-13.3 \mathrm{~cm} \mathrm{SL}$, arrival live in Regensburg 2 September 1999, EOD recording 28 September to 7 October 1999 at $100 \mu \mathrm{S} \mathrm{cm}^{-1}$ water conductivity and $21^{\circ} \mathrm{C}$ (EOD recording in Germany for quicker transport in Africa), presently alive,

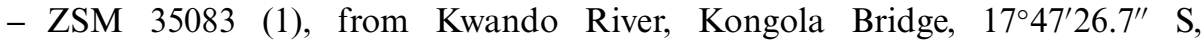
$23^{\circ} 20^{\prime} 40.0^{\prime \prime}$ E, 24 January 2001, coll.: F.H. van der Bank and B. Kramer,

- Non-types (63 specimens)from the Okavango River, Botswana, totalling at least 10 males, male size range $110-181 \mathrm{~mm}$ SL, juvenile/female size range 54-169 mm SL, examined:

- SAIAB 79140 (9), ZSM 35079 (1), ZSM 35080 (3), ZSM 35081 (6) from the Okavango River, Makwena Lodge, near the township of Etsha no. 6, $19^{\circ} 07^{\prime} 30^{\prime \prime}$ S, $22^{\circ} 22^{\prime}$ E, coll.: F.H. van der Bank, J. Engelbrecht and B. Kramer, 20-22 January 2001, locality 7 on Figure 1,

- SAIAB 79143 (6), ZSM 35096 (5), and 24 specimens presently alive in aquarium, from the Okavango River at Guma Lagoon, $18^{\circ} 57^{\prime} 46.6^{\prime \prime} \mathrm{S}, 22^{\circ} 22^{\prime} 25.3^{\prime \prime} \mathrm{E}$, coll.: F.H. van der Bank and B. Kramer, 10-12 August 2004, close to locality 7 on Figure 1,

- SAIAB 79141 (1), ZSM 35095 (1), and seven specimens presently alive in aquarium, details as in preceding paragraph, except for locality at Makwena, $19^{\circ} 03^{\prime} 13.85^{\prime \prime} \mathrm{S}, 22^{\circ} 22^{\prime} 42.6^{\prime \prime} \mathrm{E}, 12$ August 2004.

Samples examined for genetics. DNA samples are stored at Institute of Pharmacy and Molecular Biotechnology, Heidelberg University (IPMB).

- IPMB 44903-44905, Namibia: Upper Zambezi: Kalimbeza, 17³2'27.3" S, 24³1'26.2” E, coll. F.H. van der Bank and B. Kramer, 21 August 1999;

- IPMB 44638-44640 Botswana: Okavango: Guma Lagoon, 18 57'46.6" S, $22^{\circ} 22^{\prime} 25.3^{\prime \prime}$ E, coll. F.H. van der Bank and B. Kramer, 10 August 2004; IPMB 44641, 44642, as before, but 10-12 August 2004; GenBank accession numbers: (KC202230-KC202237).

\section{Type locality}

Upper Zambezi River in East Caprivi (Namibia); specifically Upper Zambezi River between Lisikili and Kalimbeza (or Kalambesa, $17^{\circ} 33^{\prime} \mathrm{S}, 24^{\circ} 29^{\prime}$ E to $17^{\circ} 32^{\prime} 27.3^{\prime \prime} \mathrm{S}$, $24^{\circ} 31^{\prime} 26.2^{\prime \prime}$ E; 22-26 km straight line downstream from Katima Mulilo; Figure 1, no. 5).

The first record of G. macrolepidotus for the Upper Zambezi is that of Gilchrist and Thompson (1917, p. 562), specifying Lialui, Barotseland as origin. For a description, the authors refer to Gilchrist and Thompson (1913, p. 330), a description of South African specimens that Kramer et al. (2007) have referred to M. pongolensis (Fowler, 1934). The presence of G. macrolepidotus in the Upper Zambezi System was confirmed by Jubb (1958). Another possible synonym would be G. okavangensis if it were available 
(this name should be dropped from a list of synonyms, as suggested by Kramer et al. 2007). Upper Zambezi and Okavango specimens were recognized as representing a new species, $M$. altisambesi, that is well differentiated from M. macrolepidotus (Peters, 1852) by Kramer et al. (2007).

Marcusenius angolensis (Boulenger, 1905)

(Figure 4B)

Gnathonemus angolensis Boulenger, 1905, p. 458. Origin, Quanza River, Angola.

Gnathonemus macrolepidotus angolensis: Poll and Gosse 1963, p. 93.

Marcusenius angolensis: Taverne 1971a, p. 103; Taverne 1971 b, p. 134; Taverne 1972, p. 166.

Marcusenius macrolepidotus angolensis: Gosse 1984, p. 86. "Distribution: Angola (Zaïre basin and Upper Zambezi), Zaïre, (Upper basin).” In consequence, Skelton et al. (1985) state that Marcusenius macrolepidotus angolensis applies to the Upper Zambezi form.

Marcusenius angolensis: Kramer et al. 2007, p. 680-681.

\section{Type specimens}

Holotype (unique): BMNH 1905.5.29.64, examined.

Non-types, examined:

- USNM 042332 Marcusenius macrolepidotus angolensis, 4 specimens, "pond near Cunga, Angola, Africa”, coll: Brown, W.H., 25 December 1889, assuming this location refers to the one Cunga that is associated with the Quanza, near Malanga in the Lower Quanza region, at 9'25'29" S, 16 $21^{\prime} 19^{\prime}$ " E. (There are at least four more Cungas in Angola that are associated with the Cunene (in the southwest), the Cuito or the Kwando (southeast), a tributary of the Lower Congo (northwest), and an independent coastal stream discharging into the Atlantic south of the Congo mouth, northwest).

- USNM 042357 Marcusenius macrolepidotus angolensis, three specimens, "Quanza R., Angola", coll: Brown, W.H., "no tag in jar, no entry in date field of ledger, if locality is correct, date probably Dec. 1889".

- ZSM 20948-949, Gnathonemus angolensis Blgr 1905, two specimens, "Cuanza/Angola, SW-Afrika, III.1957, leg. Schoenfeldt, det. Terofal".

- BMNH 1907.6.29.231-233, Gnathonemus angolensis Blgr 1905, three specimens, "Cunene, Mossamedes", purchased Dr W. Ansorge. Mossamedes refers to the district of Mossamedes, then Angola's southernmost district bordering Namibia (Stieler's Hand-Atlas, 1910).

\section{Type locality}

Angola: Quanza River (no. 2, Figure 1).

The former subspecies M. macrolepidotus angolensis (Poll and Gosse, 1963) refers to the single specimen of G. angolensis Boulenger 1905 from the Quanza River in Angola (no more specific origin than the Lower Quanza is indicated by Boulenger 1910). The fishes (i.e., fish species) of the upper Quanza appear to be related to the fishes of the Zambezi basin and to the Cunene (Trewavas 1973; P. Skelton 1994). 
Headwaters of both river systems arise just northeast of the city of Huambo on the Plateau of Bié, less than $20 \mathrm{~km}$ apart (the Cutato for the Quanza; Operational Navigation Chart, ONC N-3, $1: 1,000,000)$. Huambo is at an altitude of $1700 \mathrm{~m}$, and both rivers flow in opposite directions. The type specimen, whose origin Boulenger (1905) gives only as "Quanza River, Angola", originates from the distant and tropical Lower Quanza, as concluded from the geographical detail given by J.W. Ansorge in Boulenger (1910). "The Lower Quanza ecoregion is considered its own distinct bioregion because the Zambezian fauna is absent or poorly represented, and a number of endemic species have been described" (Thieme et al. 2005, p. 303). Seven specimens from USNM are also given as originating from the Quanza River, however, it is not clear from which section of this river, of which by far the longest section lies in the mountains, with many rapids and waterfalls. Two specimens from ZSM are listed as originating from the Quanza River (without further detail), however, this information could be incorrect (D. Neumann, personal communication). From the report by Hellmich (1957) and additional information at ZSM these specimens could originate from close to Ganda $\left(13^{\circ} 00^{\prime} 30^{\prime \prime} \mathrm{S}, 14^{\circ} 37^{\prime} 25^{\prime \prime} \mathrm{E}\right)$, which lies on a small coastal system between Huambo and Benguela (the Jamba, a tributary of the Cubal). For comparison, the anatomical measures of these nine specimens are also given in Table A1 (in Appendix A) but cannot be used for taxonomic decisions unless their origin is known with greater precision.

Marcusenius multisquamatus sp. nov.

(Figure 4E)

\section{Type specimens}

Holotype: SAIAB 78781 (field no. KUNE24), live SL $20.9 \mathrm{~cm}$, fixed SL $20.2 \mathrm{~cm}$, fixed TL 22.9 cm, male, Namibia: Cunene River: Epupa Falls, Hot Springs Campsite, estimated $300 \mathrm{~m}$ upstream from the Falls, $17^{\circ} 00^{\prime} 07^{\prime \prime} \mathrm{S}, 13^{\circ} 14^{\prime} 57^{\prime \prime} \mathrm{E}$, about $600 \mathrm{~m}$ altitude, 15 August 2006, coll. E. Swartz, B. Kramer and L. da Costa at $\leq 1.5 \mathrm{~m}$ water depth. Paratypes: SAIAB 78780 (2), SAIAB78792; ZSM 38526 (2), ZSM 38527 (2), size range 10.1-20.2 cm SL, Namibia: Cunene River: Epupa Falls, Hot Springs Campsite, estimated $300 \mathrm{~m}$ upstream from the Falls, $17^{\circ} 00^{\prime} 07^{\prime \prime} \mathrm{S}, 13^{\circ} 14^{\prime} 57^{\prime \prime} \mathrm{E}$, about $600 \mathrm{~m}$ altitude, coll. E. Swartz, B. Kramer, and L. da Costa at $\leq 1.5 \mathrm{~m}$ water depth, Cunene River water at Hot Springs: Saturday, 12 August 2006, $12.50 \mathrm{~h}: 19.9^{\circ} \mathrm{C}, 48 \mu \mathrm{S} \mathrm{cm}^{-1}$, from 11 Augure 2006-17 August 2006.

Non-types. SAIAB 78785 (2), SAIAB 78789 (2), ZSM 38528, ZSM 38529 (2), size range 11.6-15.4 cm SL (live), Ruacana Falls, Hippo Pool Campsite, just below the Falls, $17^{\circ} 24^{\prime} 24^{\prime \prime} \mathrm{S}, 1^{\circ} 13^{\prime} 01^{\prime \prime}$ E, about $800 \mathrm{~m}$ altitude, coll. E. Swartz and B. Kramer, at $\leq 1.5 \mathrm{~m}$ water depth, Cunene River water at Hippo Pool: Saturday, 19 August 2004, $10.00 \mathrm{~h}: 21.1{ }^{\circ} \mathrm{C}, 45.8 \mu \mathrm{S} \mathrm{cm}{ }^{-1} ; 20$ August $2006,10.00 \mathrm{~h}, 19.8{ }^{\circ} \mathrm{C}, 45.4 \mu \mathrm{S} \mathrm{cm}{ }^{-1}$; 21 August, $10.18 \mathrm{~h}, 19.4^{\circ} \mathrm{C}, 44.2 \mu \mathrm{S} \mathrm{cm}^{-1}$; from 18 August 2006 to 23 August 2006.

ZSM 41761 (11), specimens R1-R11, from the Cunene River mouth, 17 $15.606^{\prime} \mathrm{S}$, $11^{\circ} 45.892^{\prime}$ E, altitude 2 m, 15 December 2009, coll. F.H. van der Bank; ZSM 41762 (2), specimens 49 and $49,17^{\circ} 16.325^{\prime} \mathrm{S}, 1^{\circ} 47.177^{\prime} \mathrm{E}, 8$ November 2010 , coll. S. Voges; ZSM 41765, specimen C113, same place, 17 January 2011, coll. S. Voges; ZSM 41763, specimen Ü7, same place, 13 July 2011, coll. S. Voges; ZSM 41764 (9), specimens $\ddot{A} 110-\ddot{A} 118$, same place, 22 November 2011, coll. S. Voges. The specimens from the Cunene mouth were not studied for EOD. 
Samples examined for genetics. DNA samples are stored at the Institute of Pharmacy and Molecular Biotechnology, Heidelberg University (IPMB). IPMB 57459-57469, Namibia: Cunene River Mouth, $17^{\circ} 15.606^{\prime}$ S, $11^{\circ} 45.892^{\prime}$ E, coll. F.H. van der Bank, 15 December 2009;

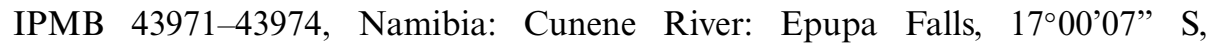

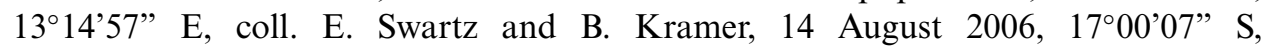
E01314'57" E; IPMB 43975-43978, as before, but 15 August 2006; IPMB 43993, as before, but 17 August 2006;

IPMB 43980, Namibia: Cunene River: Ruacana Falls, 17²4’24” S, 014¹3’01” E, coll. E. Swartz and B. Kramer, 19 August 2006; IPMB 43986, 43988, as before, but 21 August 2006; IPMB 43990, as before, but 22 August 2006; GenBank accession numbers: (KC202227-KC202230; KC202238-KC202258).

\section{Type locality}

Cunene River just above the Epupa Falls (Angolan/Namibian border, locality no. 9 on Figure 1.

\section{Diagnosis}

Body moderately long, prominent mobile and forward-extending mental lobe on lower jaw, median fins set well back with dorsal fin shorter than and originating behind anal fin, depth of caudal peduncle 38\% (34-43\%) of its length, $24(23-25)$ dorsal fin rays, 30 (28-31) anal fin rays, 59 (56-64) scales in lateral series, 13 (12-16) scales around caudal peduncle, HL (head length) 20\% (19-21\%) of SL, BD (body depth) $29 \%$ (27-32\%) of SL, LD (dorsal fin length) 19.4\% (18.1-22.3\%) of SL, LSo (length of snout) $48 \%$ (45-50\%) HL, LA (anal fin length) $24.2 \%$ (22.7-25.3\%) of SL, CPL (length of caudal peduncle) $18.3 \%$ (16.3-19.9\%) of SL. (See also Remarks.)

\section{Description}

Head with terminal mouth well in front of eye, mental lobe on lower jaw protruding beyond upper jaw. Head and body dorsolaterally compressed. Dorsal fin situated about two-thirds of standard length from snout, obliquely oriented, anteriorly higher and posteriorly lower, distal margin sometimes only slightly crescent-shaped with anterior two or three rays longer than posterior rays, number of rays $23(n=5), 24(n=4)$, $25(n=6)$; anal fin opposite dorsal fin with distinctly more anterior origin, obliquely oriented, anteriorly lower and posteriorly higher, anterior rays longer than posterior ones, especially in males where they also appear stronger and often darkened, distal margin crescent-shaped (in males only posterior to rounded, elongated anterior part of fin), number of rays $28(n=1), 29(n=4), 30(n=7), 31(n=3)$. Scales cycloid with reticulate striae, scales extending anteriorly to operculum and pectoral fins (beyond pelvic fins). Scales on caudal peduncle circumference, $12(n=5), 13(n=4), 14(n=5)$, $16(n=1)$ Caudal peduncle relatively deep, subcylindrical entire length, usually $18.3 \%$ (16.3-19.9\%) in SL (Table A1, in Appendix A). Electric organ discharge biphasic with weak pre-potential (Figure 5). Males approaching sexual maturity develop a kink in the base of the anal fin (e.g. Figure 4C) that is absent in juveniles and females where the anal fin base is straight. Colour in life: brownish grey with many distinct 


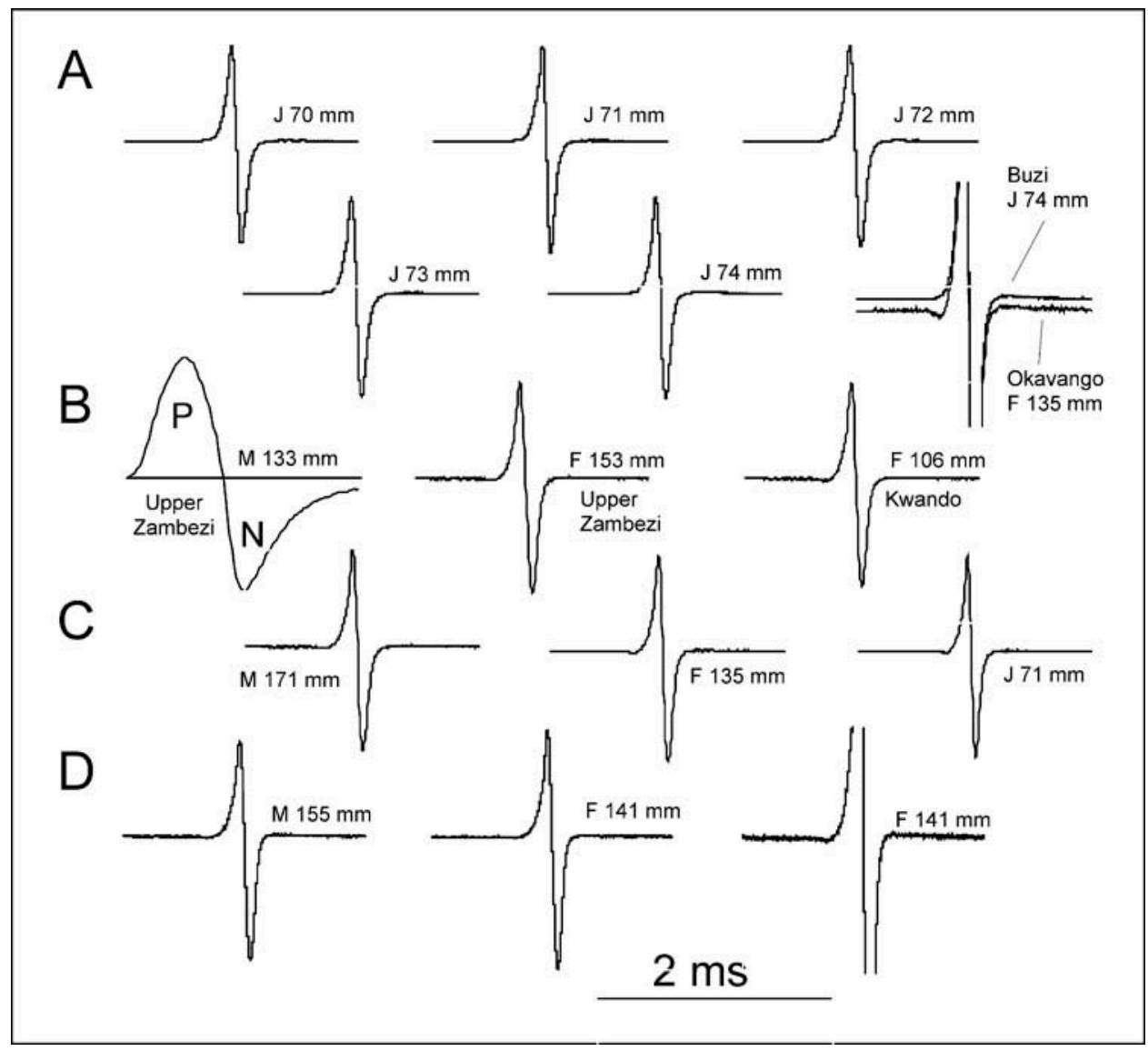

Figure 5. Electric organ discharges (EODs) recorded from fish from various origins. (A) Five specimens of Marcusenius macrolepidotus originating from the Buzi River. (B) Marcusenius altisambesi originating from the the Upper Zambezi System. Note $P$ and $N$ phases of exaggerated duration in male individual. (C) M. altisambesi originating from the Okavango delta. (D) Marcusenius multisquamatus sp. nov. originating from the Cunene River. M, male, F, female, J, juvenile individuals below size where sexual maturity is possible. Size given is SL. Note that in Buzi individuals an initial miniature potential is lacking which is present in the other forms of bulldog fish shown here (see EODs with clipped peaks, amplified $\times 3$ ).

dark-brown blotches, except on head and belly, purple hue depending on the angle of light incidence, paired fins light and transparent.

\section{Colour in preservation}

Medium brown, with darker, irregular blotches.

\section{Ecology}

The Cunene is a major, perennial and independent river that arises from the Angolan central highlands of Bié and flows southward towards the Namibian border, shortly before it turns west and breaches the coastal mountain ranges (Zebra and Baynes 
Mountains) to drain into the Atlantic. In the section between Ruacana Falls and Epupa Falls, water level was regulated by a hydroelectric company (NamPower) at Ruacana Falls. The Ruacana Falls were bare rock and completely dry, apparently because the water dammed above Ruacana Falls (Calueque Dam) was all fed into the hydroelectric power turbines. When the water level below the dam was kept high, fishing with gill nets and other methods generally proved unproductive. The Epupa Falls consist of a main fall with many lesser falls beside this over a wide front, and mormyrid EODs were demonstrated with an electro-acoustic, custom-built "fish detector" also below the Falls although the fish were not caught. Although we were warned of a high incidence of crocodiles we saw only a few, and no hippopotami. River borders were covered mainly by dense semi-aquatic shrubs at Epupa Falls, and dense reed beds also with shrubs at Ruacana Falls. Palm trees (Makalani palms) were common at Epupa, much less so at Ruacana where dicotyledonous trees dominated.

\section{Distribution}

At present known only from the lower Cunene River, from just below Ruacana Falls to the Cunene mouth. This river section forms the Angolan/Namibian border.

\section{Relationships}

Closest relationships are assumed with $M$. altisambesi to the east of M. multisquamatus sp. nov. on the basis of morphological similarity, EODs and genetics.

\section{Etymology}

Marcusenius multisquamatus sp. nov. refers to the highest number of lateral line scales among the different forms of southern African bulldog fish (excluding the three Mossamedes/Cunene specimens (BMNH 1907.6.29.231-233) from any location on the Cunene up to $300 \mathrm{~km}$ north of the Angolan/Namibian border).

\section{Remarks}

Compared with the M. angolensis holotype, M. multisquamatus sp. nov. specimens had lower counts in $\mathrm{nD}$, no. of dorsal fin rays (maximum, 25 in the latter versus 26 in the former, that is, no overlap) and $\mathrm{nA}$, number of anal fin rays (maximum, 31 versus 33), shorter LA, anal fin length (maximum, 0.253 versus 0.258 of SL) and PDL, predorsal length (maximum, 0.665 versus 0.674 of SL), smaller ratio $\mathrm{HL} / \mathrm{Na}$, head length/separation of nares (maximum, 15.52 versus 15.96 ), but a greater BD, body depth (minimum 0.271 versus 0.266 of SL).

When compared with the other Marcusenius species within the OkavangoKwando-Zambezi System, M. multisquamatus sp. nov. is characterized by a specific morphology and EOD in multivariate analysis, specific bands in genomic ISSR fingerprinting, and as a monophyletic taxon in mitochondrial DNA (mtDNA) cytochrome $b$ analysis. To identify a specimen in hand it is best to rely on several characters in combination to exclude mistakes due to outliers. The 90th percentile of the distribution of HL (measured as HL/SL, head length to standard length) of M. multisquamatus sp. nov. specimens, is shorter than the 10th percentile for M. macrolepidotus (together with $M$. angolensis, shortest $\mathrm{HL}$ of all). The $\mathrm{BD} / \mathrm{SL}$ ratio (body depth to standard length) of M. multisquamatus sp. nov. overlaps with that of M. macrolepidotus by 
less than one quartile; the same holds true for the distributions of $\mathrm{nA}$ (no. of anal fin rays), $\mathrm{nD}$ (no. of dorsal fin rays), LD/SL (ratio of dorsal fin length to standard length) in which the means or medians are greater for $M$. multisquamatus sp. nov., and SPc, number of scales around caudal peduncle in which the median for $\mathrm{M}$. multisquamatus sp. nov. is smaller. The EOD of M. multisquamatus sp. nov. has a leading head-negativity of miniature amplitude that is usually not present in the $M$. macrolepidotus EOD. Marcusenius multisquamatus sp. nov. and M. macrolepidotus are clearly differentiated in ISSR bands 2, 6 and 8 (Table 4).

There is less than a $10 \%$ overlap of distributions between the greater $\mathrm{LSo} / \mathrm{HL}$ (length of snout to head length) of M. multisquamatus sp. nov. specimens compared with that of $M$. altisambesi from the Upper Zambezi, and less than $25 \%$ overlap for $M$. altisambesi from the Okavango. Also, there is less than one quartile overlap for LA/SL (anal fin length to SL), LSc/HL (length of snout to head length) and CL/HL (chin length to head length) of $M$. altisambesi from the Upper Zambezi compared with M. multisquamatus sp. nov. and less than one quartile overlap for lower SLS (no. of lateral line scales) of $M$. altisambesi from the Okavango compared with $M$. multisquamatus sp. nov. Okavango bulldog fish are distinguished by an SPc (no. of scales around caudal peduncle) of exclusively 12 (median 12, same median for Upper Zambezi bulldog fish) whereas SPc ranges from 12-16 in M. multisquamatus sp. nov. (median, 13). ISSR band 2 is specific for M. multisquamatus sp. nov. and band 6 for M. altisambesi.

\section{Marcusenius macrolepidotus (Peters, 1852)}

(Figure 4A)

Nominal species in bold face.

Mormyrus macrolepidotus Peters, 1852a, p. 275.

Mormyrops macrolepidotus: Marcusen 1864, p. 142.

Gnathonemus macrolepidotus: Boulenger 1898, p. 804.

Gnathonemus macrolepidotus macrolepidotus: Poll and Gosse 1963, p. 93.

Marcusenius macrolepidotus: Taverne 1971a, p. 103.

Gnathonemus okavangensis Pappenheim 1907, p. 354, nomen dubium.

Gnathonemus moeruensis Boulenger, 1915, p. 163; Jackson 1961, p. 32 (most probably a subspecies of Gnathonemus macrolepidotus)

Marcusenius moeruensis: Taverne 1971a, p. 102.

Gnathonemus graeverti Steindachner, 1914, p. 536 (in full: Steindachner 1916); Matthes 1967, p. 4 (synonymy with Gnathonemus macrolepidotus). Marcusenius graeverti: Taverne 1971a, p. 103.

\section{Type specimens}

ZMB 3678 (lectotype L. Seegers 13.04.1993) from Tete, Lower Zambezi, Mozambique, with paralectotypes ZMB 6730 (one specimen), 3677 (one specimen), and 32043 (three specimens; Seegers, 1996), all examined.

Non-types, examined:

- Lower Zambezi System: SAIAB 60847, coll: Bills R., 1 August 1999, tributary of the Lower Zambezi in the delta region, southeast of Marromeu, 18 33'54” S, $35^{\circ} 39^{\prime} 46^{\prime}$ E, 81 specimens, size range 52-104 mm SL, locality 2 on Figure 1, 
- Buzi System: SAIAB 67369, coll: Bills R., 29 September 2002, first tributary of the Lucite River leaving Dombe Nyangapwa Stream, which is part of the middle Buzi River System, on the road east of Dombe, Manica Province, 1958'00” S, $33^{\circ} 24^{\prime} 52^{\prime \prime}$ E, 25 specimens, size range $70-143 \mathrm{~mm} \mathrm{SL}$, locality 3 on Figure 1,

- Five live specimens from the Buzi System, same location as SAIAB 67369, R. Bills coll., arrived 8 October 2002 in Regensburg, Germany, studied for EOD and meristic characters, size range $79-88 \mathrm{~mm} \mathrm{SL}$, still alive.

- Samples examined for genetics. DNA samples are stored at Institute of Pharmacy and Molecular Biotechnology, Heidelberg University (IPMB). IPMB 22682, 22684, 22685 (SAIAB 67369), Mozambique: Buzi System: Lucite River: Nyangapwa Stream, $19^{\circ} 58^{\prime} 00^{\prime}$ S, $33^{\circ} 24^{\prime} 52^{\prime}$ E, coll. R. Bills, S. Chimela and A. Chivindzi, 29 September 2002; IPMB 22686 (SAIAB 61592), Mozambique: Lower Zambezi: Marromeu, 18 ${ }^{\circ} 7^{\prime}$ S, 35 57' E, coll. R. Bills, 11 August 1999; IPMB 22689 (SAIAB 61603), Mozambique: Lower Zambezi: Lagoon behind sugar fields, $18^{\circ} 19^{\prime} \mathrm{S}, 35^{\circ} 55^{\prime} \mathrm{E}$, coll. R. Bills, 13 August 1999; GenBank accession numbers: (KC202222-KC202226).

\section{Type locality}

Mozambique: Lower Zambezi: Tete (no. 1, Figure 1), and tributaries to the Lower Zambezi, also Licuare River (Zambezi delta region). For more detail, Kramer et al. (2007).

Since Taverne's (1971b) major revision of several genera of the Mormyridae, there are no members of Gnathonemus in southern Africa. Two subspecies of M. macrolepidotus were recognized (Poll and Gosse 1963): M. m. macrolepidotus and M. m. angolensis, listed by Gosse (1984). Based on morphology, Kramer et al. (2007) resurrected the latter subspecies as a valid species, and in consequence dropped the former subspecies. The origin of G. moeruensis Boulenger 1915, a single specimen from Lake Mweru in the Democratic Republic of Congo (Zaïre)/Zambia, west of Lake Tanganyika, forms part of the Lualaba/Congo drainage system, and from morphology the synonymization appears questionable to Kramer et al. (2007). Also synonymized with G. macrolepidotus was G. graeverti Steindachner 1914 whose origin is the Ruaha, an east-flowing river south of Dar es Salaam, Tanzania; the unique holotype is lost; the synonymization is questionable (Kramer et al. 2007). G. okavangensis Pappenheim 1907 is "not available".

\section{Hippopotamyrus szaboi Kramer et al., 2004}

Samples examined for genetics. DNA samples are stored at Institute of Pharmacy and Molecular Biotechnology, Heidelberg University (IPMB). IPMB 15761, 15765,

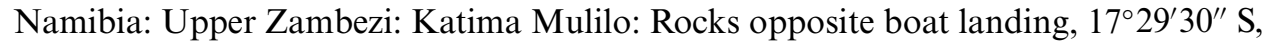

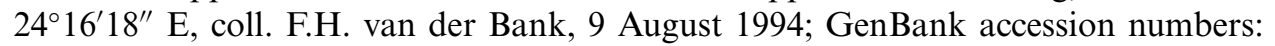
(KC202214, KC202215).

\section{Marcusenius devosi Kramer et al., 2007}

Samples examined for genetics. IPMB 22665, 22667-22669, Kenya: Tana River: Tana Primate Research Centre, $1^{\circ} 52^{\prime} 38.1^{\prime \prime} \mathrm{S}, 40^{\circ} 8^{\prime} 22.5^{\prime \prime}$ E, coll. L. DeVos and B. Kramer, 5 September 2001; GenBank accession numbers: (KC202218-KC202221). 
Pollimyrus cf. marianne Kramer et al., 2003

Samples examined for genetics. IPMB 16543, 16545, Namibia: East Caprivi: Kwando R: Kongola Bridge, 17 $47^{\prime} 26.7^{\prime \prime}$ S, $23^{\circ} 20^{\prime} 40^{\prime \prime}$ E, coll. F. H. van der Bank; GenBank accession numbers: (KC202216- KC202217).

\section{Results}

\section{Morphological comparisons}

A critical comparison of allopatric populations of the bulldog fish, M. macrolepidotus (Peters, 1852), has revealed at least five rather than a single, widespread species (Kramer et al. 2007). The geographically closest to the Cunene form of bulldog fish is the new species $M$. altisambesi, present in the Okavango and the Upper Zambezi systems (Figure 4). Also considered in the present study are topotypical M. macrolepidotus from the Lower Zambezi River, and M. angolensis (Boulenger, 1905), a resurrected species from the Angolan Quanza River. Marcusenius pongolensis (South Africa) and M. devosi (Tana River, Kenya), both from rivers draining into the Indian Ocean, are so greatly differentiated and distant that they are not compared in the present study.

A principal components analysis on the morphometric data (Appendix A, Table A1) of all allopatric samples with $n \geq 15$ specimens was performed that included specimens from the Cunene River (the 15 escarpment specimens), Okavango, Upper Zambezi and Lower Zambezi (and not the Quanza which was represented by the unique holotype specimen of $M$. angolensis only). The 14 characters analysed were those listed in Table 1. The first three principal components (PC1-PC3) represented about $58 \%$ of the variation, that is, there was a considerable amount of redundancy in the data set (Appendix B, Table B1). Considering only significant loadings, PC1 represents a gradient for a long and deep trunk (significance "excellent" for PDL, predorsal length, and PAL, preanal length, "good" for BD, body depth) but short head (HL, "poor"), going together with a deep but short caudal peduncle (both "very good"), short tail section and low number of pericaudal scales (both "fair"); or, vice versa, short, low trunk with long head (and so on). PC2 represents a gradient for long unpaired fins with high numbers of rays, long rear body section, again correlated with a short head, a short trunk, and short LSo (length of snout). PC3 was dominated by a trend for a high number of SPc (no.of scales around caudal peduncle) being correlated with a long anal fin but short and deep caudal peduncle, short snout, low number of SLS (no. of lateral line scales) and $\mathrm{nD}$ (no. of dorsal fin rays). With some simplification, PC1 may be termed a "trunk gradient", PC2 an "unpaired fin gradient", and PC3 a "caudal peduncle gradient".

It seems necessary to first clarify the relationship of the Cunene specimens ( $n=15$ ) with topotypical M. macrolepidotus from the Lower Zambezi $(n=42)$. The two samples are completely separated in terms of principal components coordinates PC1-PC3 and discriminant analysis, demonstrating their independent status (Figure 6A, B). Compatible with this result is the outcome of a multivariate analysis of variance over all samples $\left(\mathrm{F}_{\geq 14,163} \geq 21.73\right.$ for all four test variables, $p<0.0001$ for erroneously rejecting the hypothesis of identity of populations; Table 1). As shown by subsequent analyses of variance, all 14 characters but one included in the analysis differed significantly among origins $\left(\mathrm{F}_{3,174} \geq 5.903, p \leq 0.0007\right.$; Table 1$)$. Pairwise 


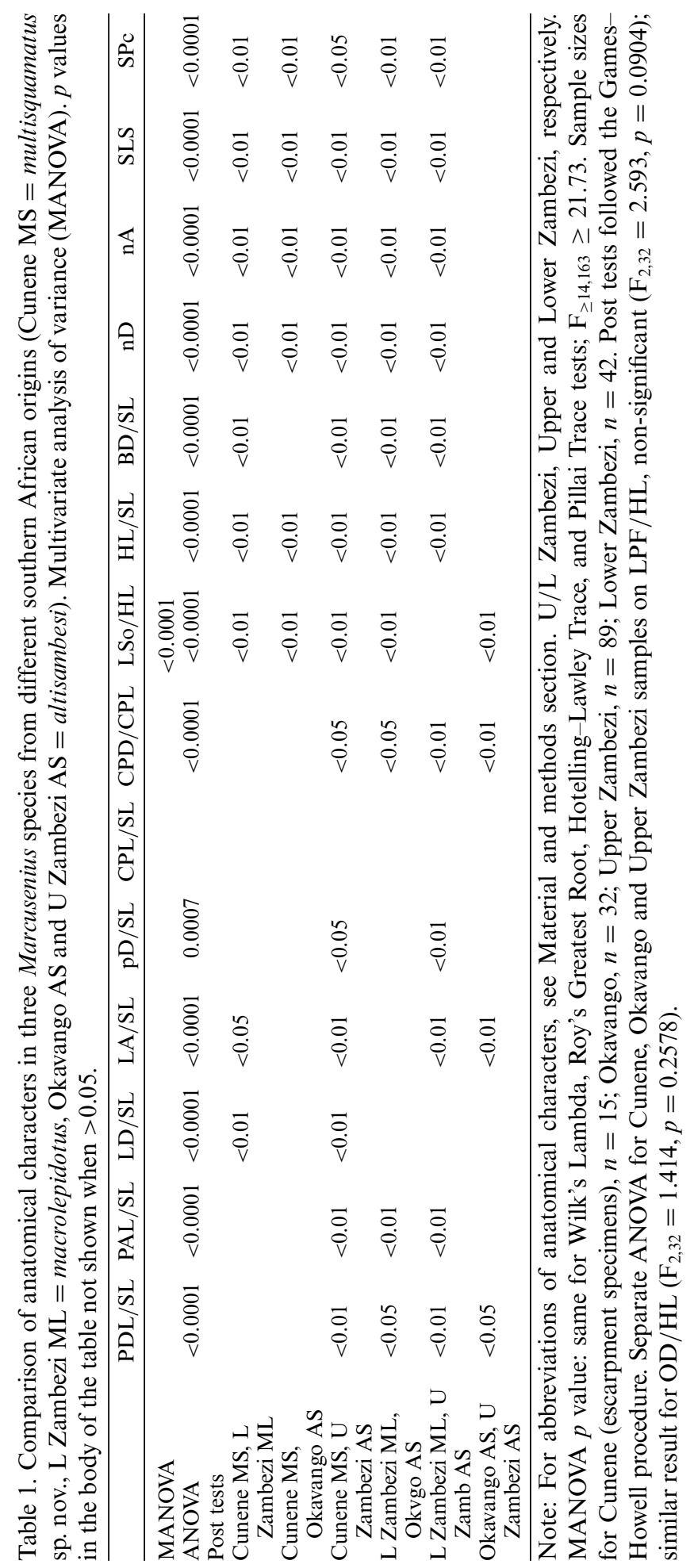



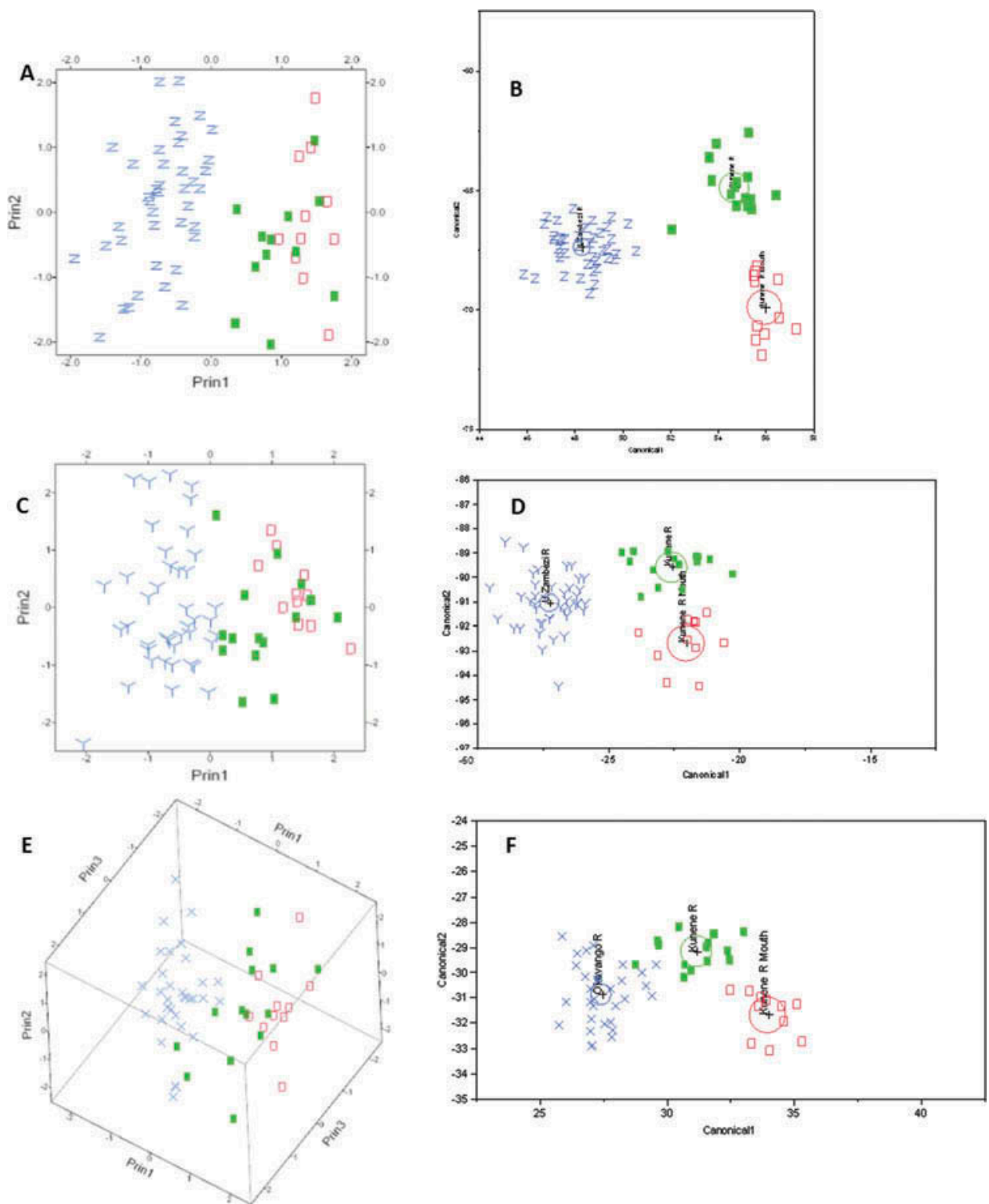

Figure 6. Multivariate analysis on morphology for three Marcusenius species in southern Africa. (A, C, E) Principal components analyses on correlations for 14 anatomical characters; (B, D, F) discriminant analyses on same data to their left. Prin1, Prin2 and Prin3 axes represent the first three principal components. Green solid squares: Marcusenius multisquamatus sp. nov. specimens from Cunene River (escarpment, $n=15$ ); red open squares, from Cunene River Mouth $(n=11)$. Blue $\mathrm{Z}$ symbols, Marcusenius macrolepidotus specimens from Lower Zambezi River $(n=42)$; blue Y symbols, Marcusenius altisambesi specimens from Upper Zambezi River $(n=42)$; blue X symbols, $M$. altisambesi specimens from Okavango River $(n=32)$. [Characters analyzed: PDL/SL, PAL/SL, LD/SL, LA/SL, pD/SL, CPL/SL, CPD/CPL, LSc/HL, HL/SL, $\mathrm{BD} / \mathrm{SL}, \mathrm{nD}, \mathrm{nA}, \mathrm{SPc}, \mathrm{SLS}]$ 
comparisons between Lower Zambezi and Cunene samples yielded significant differences for eight characters, including all meristic ones, but also LD (dorsal fin length), BD (body depth), HL (head length), LSo, length of snout $(P<0.01$, Games-Howell post hoc test), that is, mainly PC2 and PC3 loading characters.

Samples of $M$. altisambesi have previously been shown to differ significantly from M. macrolepidotus samples from the Lower Zambezi (Kramer et al. 2007). In the present study, Upper Zambezi samples $(n=89)$ differed from Lower Zambezi samples $(n=42)$ in 11 characters, whereas Okavango samples $(n=32)$ differed in eight characters (Table 1). In principal component analysis coordinates (PC1-PC3), Cunene samples occupied non-overlapping spaces in comparison with Upper Zambezi samples and also with Okavango samples with the exception of one point for the latter (Figure 6C-F). Cunene samples differed from Upper Zambezi samples significantly in 10 characters, and from Okavango samples in six characters (Table 1). Cunene samples had higher counts than Okavango samples in all four meristic characters, but a shorter HL (head length) with relatively longer LSo (length of snout), again characters loading strongest on PC2 or PC 3 or higher.

Cunene River mouth samples $(n=11)$ overlapped with the other Cunene samples in principal component analysis coordinates, except that they tended towards even stronger separation from the M. macrolepidotus and $M$. altisambesi samples (Figure 6A, C, E). Discriminant analyses comparing the two Cunene samples with the two other species confirmed differentiation from both $M$. macrolepidotus and M. altisambesi, but also showed rather marked differentiation between the two Cunene samples along Canonical 2 (Figure 6B, D, F).

There could be more affinity of the lower Cunene form of bulldog fish with M. angolensis (Boulenger, 1905) from the Quanza River. However, the unique holotype was beyond the range of all lower Cunene specimens combined in several characters: above range in $\mathrm{nA}$ (no. of anal fin rays), $\mathrm{nD}$ (no. of dorsal fin rays), PDL (predorsal length), LA (anal fin length), HL/Na (head length/separation of nares), and below range in BD, body depth (Appendix A, Table A1). Nor can lower Cunene specimens be referred to one of the three other Museum samples from the Quanza River, whose exact origins are as yet also unknown. There is no overlap in four to five characters between Cunene samples and (1) USNM 042332 ("pond near Cunga, Angola, Africa", $n=4$ ), nor of Cunene samples with (2) USNM 042357 ("Quanza R., Angola, Africa", $n=3$ ), nor of Cunene samples with (3) ZSM 20948-949 ("Cuanza/Angola, SW-Afrika", $n=2$ ). For sample (1), these non-overlapping characters are PAL (preanal length), CPL (length of caudal peduncle), HL (head length), SLS (no. of lateral line scales) and PPF (distance pectoral to pelvic fin origins); for sample (2), PDL (predorsal length), CPD (depth of caudal peduncle), BD (body depth), nA (no. of anal fin rays); and for sample (3), LSo (length of snout), BD, nD (no. of dorsal fin rays), SLS (no. of lateral line scales) (Table A1). The four Museum samples of bulldog fish, purportedly all originating from the Quanza River, differ markedly from each other, perhaps because they were sampled from different sections of the river, the upper and middle sections of which are broken by rapids and waterfalls.

The present sample of Cunene escarpment bulldog fish also differs substantially from BMNH 1907.6.231-233, three specimens from "Cunene, Mossamedes" of 1907, which most likely refers to the Cunene River (also suggested by Bell-Cross and Minshull 1988 commenting upon Serranochromis), district of Mossamedes (the community of Moçâmedes, now Namibe, lies on the Atlantic Ocean and not on the 
Cunene, $230 \mathrm{~km}$ north of the Cunene mouth). The district of Mossamedes used to be the southernmost area of Angola bordering Namibia, and included the entire Lower Cunene River from about $14^{\circ} 53^{\prime} \mathrm{S}$ southward to its mouth. Therefore, the Mossamedes sample may originate from any point on the Lower Cunene River up to about $300 \mathrm{~km}$ north of Ruacana (Stieler's Hand-Atlas of 1910). The Mossamedes sample's values for PAL, preanal length, and CPD, depth of caudal peduncle, are smaller, but for CPL, length of caudal peduncle, greater than those of the present Cunene escarpment sample (no overlap). The Mossamedes sample's largest values for PDL, predorsal length and PPF (distance pectoral to pelvic fin origins) overlap with the 10th percentile only for Epupa and Ruacana bulldog fish, whereas the smallest values for $\mathrm{pD}$ (distance dorsal fin origin to end of caudal peduncle) and LSc (length of snout) of the former overlap with the 90th percentile only of the latter (Table 11).

\section{Electric organ discharges}

There was little difference among the waveforms of EODs recorded from female Cunene (escarpment) bulldog fish and those from the Okavango or Upper Zambezi (Table 2). Similar to the latter two, and in contrast to M. macrolepidotus (Buzi River specimens), Cunene escarpment specimens' EODs of both sexes showed an initial head-negativity of miniature amplitude and of even weaker strength (Figure 5). Namp in Cunene bulldog fish EODs appeared to be stronger, and Narea was greater, than in Buzi specimens' EODs. For males there was also no clear differentiation of Cunene EODs from Okavango EODs; they also resembled the EODs displayed by Upper Zambezi males when recorded in local "winter" (not, however, in "summer"; Table 3). No data for local "summer" are available for Cunene fish at present.

The EOD of a big male bulldog fish caught in a trap at Epupa Falls did not differ notably from those of the smaller fish (Figure 7). However, the two individuals from Ruacana Falls displayed EODs of somewhat longer duration than the Epupa individuals. We are not aware of any fish barriers between the two sites, which are about $115 \mathrm{~km}$ (straight line) apart at 800 and $600 \mathrm{~m}$ altitude, respectively.

The discriminant analysis of Figure 8 compares female and juvenile EODs of Lower Zambezi, Upper Zambezi, Okavango and Cunene escarpment specimens excluding all males except those from the Cunene escarpment population. Males of $M$. altisambesi were excluded because they display a marked seasonal sexual dimorphism of their EOD waveform (Kramer 1997), and are quite variable among themselves even in local "winter". Males of the Cunene population were included because there was no obvious sex difference, and otherwise the specimen numbers would have been too low for statistics. With only seven Cunene specimens, four of them males, discriminant analysis showed their EODs as a separate entity from Lower and Upper Zambezi as well as Okavango specimens.

\section{Genetic studies}

The phylogenetic reconstruction of mtDNA sequences with maximum likelihood shows that $M$. altisambesi and $M$. multisquamatus sp. nov. are clearly separated (bootstrap support 100\%) from M. macrolepidotus (Figure 9). Mean genetic distances between sequences of cytochrome $b$ from $M$. macrolepidotus vs $M$. altisambesi and M. multisquamatus sp. nov. are in the range of 3.0-5.2\% (p-distance), indicating a 
Table 2. Electric organ discharge waveform characters in females and juveniles of three Marcusenius species for samples from different southern African origins. Buzi ML $=$ macrolepidotus; Upper Zambezi AS = altisambesi; Cunene MS = multisquamatus sp. nov.

\begin{tabular}{|c|c|c|c|c|c|c|c|}
\hline Origin of samples & $\begin{array}{l}\text { Namp } \\
(V)\end{array}$ & $\begin{array}{l}\text { Pdur } \\
(\mu s)\end{array}$ & $\begin{array}{l}\text { Ndur } \\
(\mu s)\end{array}$ & $\begin{array}{l}\text { PNsep } \\
(\mu \mathrm{s})\end{array}$ & $\begin{array}{c}\text { Parea } \\
(V \times \mu s)\end{array}$ & $\begin{array}{c}\text { Narea } \\
(V \times \mu \mathrm{s})\end{array}$ & $\mathrm{SL}(\mathrm{cm})$ \\
\hline \multicolumn{8}{|l|}{ Buzi ML $(n=5)$} \\
\hline Mean/Median* & -1.097 & 182.8 & 173.8 & 86.4 & 80.8 & 90.2 & $8.1^{*}$ \\
\hline SE/SIQ* & 0.019 & 2.63 & 4.87 & 3.51 & 1.74 & 2.33 & $0.44^{*}$ \\
\hline Size range & & & & & & & $7.9-8.8$ \\
\hline \multicolumn{8}{|l|}{ Upper Zambezi AS: } \\
\hline \multicolumn{8}{|l|}{$\begin{array}{l}\text { Summer, } n=47 \\
\text { (Winter, } n=22 \text { ) }\end{array}$} \\
\hline Mean/Median* & $\begin{array}{l}-1.091 \\
(1.149)\end{array}$ & $\begin{array}{c}183 \\
(179.3)\end{array}$ & $\begin{array}{c}203.8 \\
(160.9)\end{array}$ & $\begin{array}{c}96 \\
(78.5)\end{array}$ & $\begin{array}{l}81.8 \\
(78.7)\end{array}$ & $\begin{array}{l}102.8 \\
(85.5)\end{array}$ & $\begin{array}{c}12^{*} \\
(11.3)\end{array}$ \\
\hline SE/SIQ* & $\begin{array}{l}0.022 \\
(0.02)\end{array}$ & $\begin{array}{c}3.58 \\
(2.73)\end{array}$ & $\begin{array}{l}14.76 \\
(4.42)\end{array}$ & $\begin{array}{c}3.83 \\
(1.75)\end{array}$ & $\begin{array}{c}2.56 \\
(1.15)\end{array}$ & $\begin{array}{c}4.15 \\
(1.28)\end{array}$ & $\begin{array}{l}0.79^{*} \\
(1.9)\end{array}$ \\
\hline Size range & & & & & & & $\begin{array}{l}10.1-15.7 \\
(7.2-13.1)\end{array}$ \\
\hline \multicolumn{8}{|l|}{$\begin{array}{l}\text { Okavango AS } \\
(n=28)\end{array}$} \\
\hline Mean/Median* & -1.192 & 184.1 & 165.9 & 90 & 81.4 & 99.1 & $10^{*}$ \\
\hline SE/SIQ* & 0.018 & 1.73 & 5.62 & 2.97 & 0.91 & 2.23 & $0.57^{*}$ \\
\hline Size range & & & & & & & $7.1-16.9$ \\
\hline \multicolumn{8}{|l|}{$\begin{array}{l}\text { Cunene MS } \\
\text { (escarpment, } \\
n=3 \text { ) }\end{array}$} \\
\hline Mean/Median* & -1.166 & 192.3 & 176.9 & 100.3 & 82.9 & 106.2 & $14.1^{*}$ \\
\hline $\begin{array}{l}\mathrm{SE} / \mathrm{SIQ}^{*} \\
\text { size range }\end{array}$ & 0.031 & 11.12 & 32.2 & 12.56 & 6.67 & 14.88 & $\begin{array}{c}0.49^{*} \\
13.6-14.9\end{array}$ \\
\hline
\end{tabular}

Note: Abbreviations of electric organ discharge waveform characters, Material and methods. SE, standard error; SIQ, semi-interquartile range. For Upper Zambezi, winter sample $n=22$ in parentheses (different individuals).

*Median and SIQ (semi-interquartiles) for SL only.

divergence about 5-9 million years ago (assuming a molecular clock of 0.0058 changes per site and million years, obtained for freshwater fish; Burridge et al. 2008). A p-distance above $2 \%$ is typical for the genetic distance between distinct species.

Marcusenius altisambesi and M. multisquamatus sp. nov. form monophyletic groups and are closely related. Mean genetic distances between them are 0.4 to $1.6 \%$ (p-distance), indicating a divergence between 690,000 and 2.7 million years ago. In both taxa several haplotypes are apparent, probably reflecting the specimens' origin from two mega river systems, the Upper Zambezi and the Okavango, which are tenuously linked by the Kwando River in the Caprivi Strip (Figure 1). The heterogeneity, which is also reflected by genetic distances of up to $1.2 \%$ between individuals, indicates that hybridization might have taken place or that unique lineages exist that have not yet been identified at the morphological and electrophysiological level.

Genomic fingerprinting of $M$. altisambesi, M. multisquamatus sp. nov. and M. macrolepidotus by ISSR-PCR produced a complex profile of PCR products 
Table 3. Electric organ discharge (EOD) waveform characters in males of two Marcusenius species for samples from different origins in southern Africa. Upper Zambezi AS = altisambesi; Okavango AS = altisambesi; Cunene MS = multisquamatus sp. nov. Basic statistics and leastsquares regression of EOD waveform parameters with fish standard length. Parameters for regression not shown when not significant, or non-linear, or when sample size insufficient.

\begin{tabular}{|c|c|c|c|c|c|c|c|}
\hline Origin of samples & $\begin{array}{l}\text { Namp } \\
(V)\end{array}$ & $\begin{array}{l}\text { Pdur } \\
(\mu s)\end{array}$ & $\begin{array}{l}\text { Ndur } \\
(\mu s)\end{array}$ & $\begin{array}{l}\text { PNsep } \\
(\mu \mathrm{s})\end{array}$ & $\begin{array}{c}\text { Parea } \\
(V \times \mu s)\end{array}$ & $\begin{array}{c}\text { Narea } \\
(V \times \mu \mathrm{s})\end{array}$ & $\mathrm{SL}(\mathrm{cm})$ \\
\hline \multicolumn{8}{|l|}{$\begin{array}{l}\text { Upper Zambezi AS: } \\
\text { Summer, } n=30 \\
\text { (Winter, } n=8 \text { ) }\end{array}$} \\
\hline Mean/Median* & $\begin{array}{c}-0.866 \\
(1.11)\end{array}$ & $\begin{array}{c}402.4 \\
(176.04)\end{array}$ & $\begin{array}{c}867.3 \\
(158.1)\end{array}$ & $\begin{array}{l}286.4 \\
(78.1)\end{array}$ & $221.6(78)$ & $295(82.3)$ & $12.2(13)$ \\
\hline SE/SIQ* & $\begin{array}{c}0.036 \\
(0.024)\end{array}$ & $\begin{array}{c}47.04 \\
(5.7)\end{array}$ & $\begin{array}{l}136.7 \\
(9.4)\end{array}$ & $\begin{array}{l}40.35 \\
(1.63)\end{array}$ & $\begin{array}{l}31.21 \\
(1.9)\end{array}$ & $\begin{array}{l}45.07 \\
(1.94)\end{array}$ & $\begin{array}{c}1.3 \\
(0.125)^{*}\end{array}$ \\
\hline $\mathrm{r}$ & 0.377 & $\begin{array}{l}\text { Summer: } \\
\text { sigm }\end{array}$ & $\begin{array}{l}\text { Summer: } \\
\text { sigm }\end{array}$ & $\begin{array}{l}\text { Summer: } \\
\text { sigm }\end{array}$ & $\begin{array}{l}\text { Summer: } \\
\text { sigm }\end{array}$ & $\begin{array}{l}\text { Summer: } \\
\text { sigm }\end{array}$ & \\
\hline Slope & 0.042 & & & & & & \\
\hline SE & 0.019 & & & & & & \\
\hline Y-icpt & -1.406 & & & & & & \\
\hline $\mathrm{SE}$ & 0.253 & & & & & & \\
\hline$p($ slope $)$ & 0.0401 & & & & & & \\
\hline Size range & & & & & & & $\begin{array}{c}11-18.5 \\
(12-13.3)\end{array}$ \\
\hline \multicolumn{8}{|l|}{$\begin{array}{l}\text { Okavango AS } \\
(n=10)\end{array}$} \\
\hline Mean/Median* & -1.06 & 187.6 & 216.2 & 111.9 & 83.5 & 109.8 & $14.4^{*}$ \\
\hline $\begin{array}{l}\text { SE/SIQ* } \\
\text { Size range }\end{array}$ & 0.069 & 4.08 & 20.75 & 11 & 2.753 & 6.45 & $\begin{array}{c}1.2^{*} \\
13.5-18.1\end{array}$ \\
\hline \multicolumn{8}{|l|}{$\begin{array}{l}\text { Cunene MS } \\
\text { (escarpment, } \\
n=4)\end{array}$} \\
\hline Mean/Median* & -1.21 & 209.7 & 196.7 & 99.9 & 91.7 & 117.1 & $15.8^{*}$ \\
\hline $\begin{array}{l}\text { SE/SIQ* } \\
\text { Size range }\end{array}$ & 0.031 & 13 & 35.2 & 7.95 & 7.49 & 14.65 & $\begin{array}{c}1.5^{*} \\
15.4-20.9\end{array}$ \\
\hline
\end{tabular}

Note: Abbreviations of EOD waveform characters are given in Material and methods. $p$ (slope) given where least-squares regression of waveform variable with SL significant; Y-icpt, Yintercept of a regression line. SE, standard error; r, Pearson correlation coefficient. SIQ, semi-interquartile range. For Upper Zambezi, winter sample $n=8$ in parentheses (different individuals).

*Median and SIQ (semi-interquartiles) for SL only.

(Table 4). Most of them were identical for the three Marcusenius species (such as bands 1, 3 and 7). Marcusenius multisquamatus sp. nov. can be distinguished from M. altisambesi by bands 2, 6 and 8. Bands 9 and 10 were detected in M. altisambesi and $M$. multisquamatus sp. nov. but not in M. macrolepidotus, and bands 12 and 13 appear almost exclusively in $M$. macrolepidotus (for band 13, one instance in M. multisquamatus sp. nov.). 


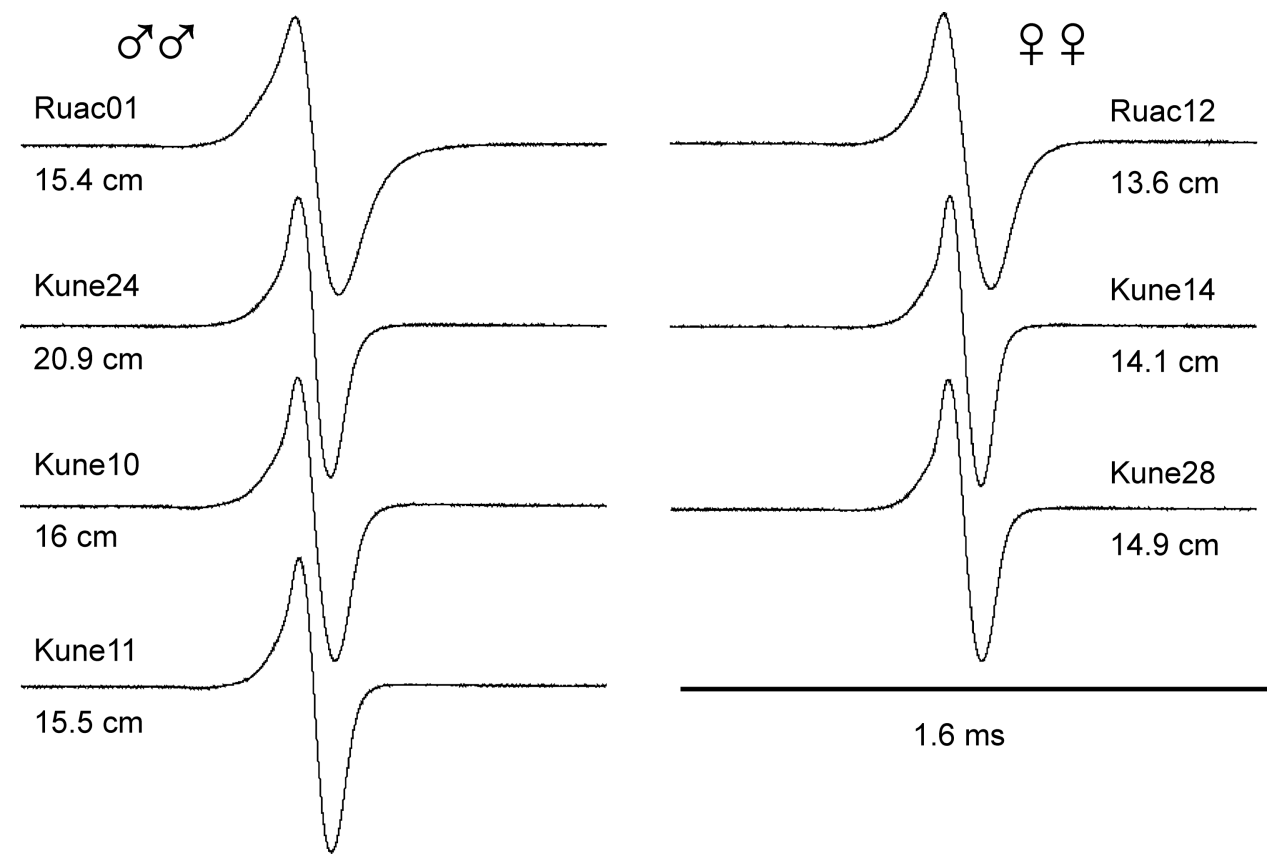

Figure 7. Electric organ dicharges (EODs) of Cunene bulldog fish individuals with SL. Left, males; right, females.

The ISSR data match the mitochondrial sequence data confirming the close relatedness between the three taxa and the sister-taxon relationship between $M$. altisambesi and $M$. multisquamatus sp. nov. It also provides additional evidence that $M$. multisquamatus sp. nov. represents a unique genetic lineage (bands 2 and 8). Whereas mtDNA is inherited maternally ISSR data are biparental. Hence the agreement between both data sets makes it less likely that the mtDNA results were caused by hybridization or a sex-biased dispersal.

\section{Discussion}

The Cunene is one of the rivers in southern Africa of which the fish fauna has been insufficiently explored. Today the Cunene is completely isolated from the Upper Zambezi/Okavango system that it must have belonged to in geological time. Exactly when the separation occurred is the object of widely differing speculations (from 0.035 to $>100$ million years ago; reviewed in Goudie 2005; Stankiewicz and de Wit 2006).

Hippopotamyrus longilateralis Kramer and Swartz, 2010 of the Cunene River was recognized as distinct from the wide-ranging species $H$. ansorgii (Boulenger, 1905) only recently. Molecular genetic data suggest that its lineage separated from that of the Upper Zambezi System 1.2-2 million years ago (or 4.3-6.8 million years ago according to the recalibrated molecular clock of Burridge et al. 2008). The present study suggests 5-9 million years for the divergence of the two Upper Zambezian species, M. altisambesi and M. multisquamatus sp. nov., from the Lower Zambezian species M. macrolepidotus, and of only 0.7-2.7 million years for the separation of the former two species. Both sequence analysis of the mitochondrial cytochrome $b$ gene 


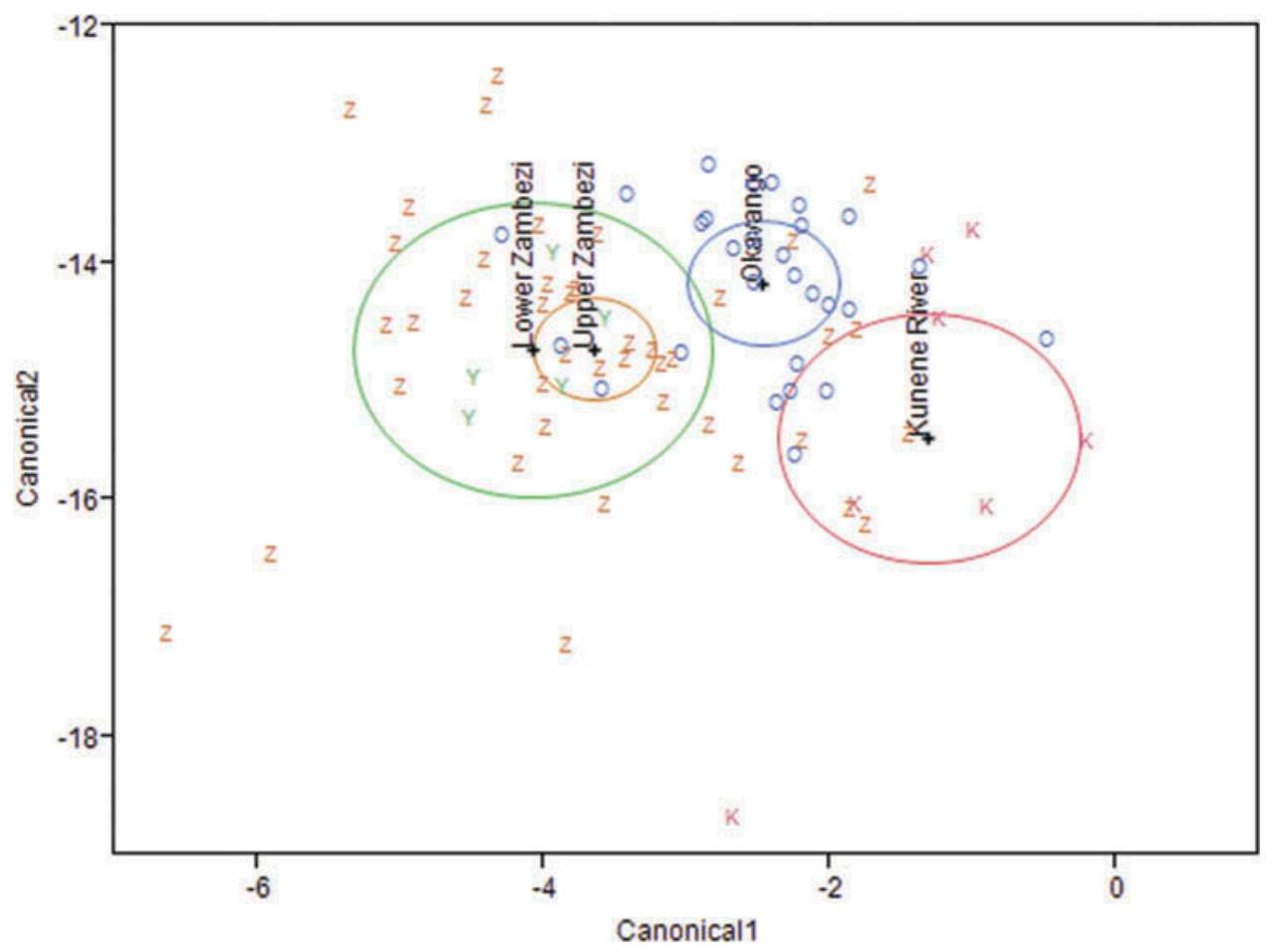

Figure 8. Discriminant analysis of electric organ discharge (EOD) variables for allopatric, southern African bulldog fish, Marcusenius sp. Red K symbols, Marcusenius multisquamatus sp. nov. from Cunene River: four males, three females $(n=7)$; blue $\mathrm{O}$ symbols, Marcusenius altisambesi from Okavango: females and juveniles $(n=28)$; orange $\mathrm{Z}$ symbols, Marcusenius altisambesi from Upper Zambezi: females and juveniles $(n=42)$; green Y symbols, Marcusenius macrolepidotus from Lower Zambezi: females and juveniles $(n=5)$. Ellipses, 95\% confidence limit to contain true mean of group. [Characters analyzed: Namp, Pdur, Ndur, PNsep, Parea, Narea].

and genomic fingerprinting confirmed $M$. multisquamatus sp. nov. as a monophyletic, homogeneous clade, reflecting its isolation from the Upper Zambezi/Okavango system for some time. This result agrees well with the estimated dispersal and speciation of serranochromine cichlids from Okavango and Upper Zambezi into the Upper Cunene at $0.2>0.4<0.6$ million years ago (Koblmüller et al. 2008). Congruent data for separation periods of fish species such as these may be useful in narrowing down the estimated time scale of the evolution of the Cunene in its present form. The larger framework of how geoecodynamics and the Tree of Life when taken together can shed light on the evolution of the Kalahari Plateau and its drainage systems is developed by Cotterill and de Wit (2011).

The isolation of the Cunene River is also evidenced by a third new mormyrid species that is endemic for that river: a new Petrocephalus species, Petrocephalus magnoculis, has been described by Kramer et al. (2012). Like H. longilateralis, this new Petrocephalus species is at present only known from the escarpment range of the Cunene, between Epupa and Ruacana Falls, in contrast to M. multisquamatus sp. nov., which also occurs at the Cunene River Mouth. 


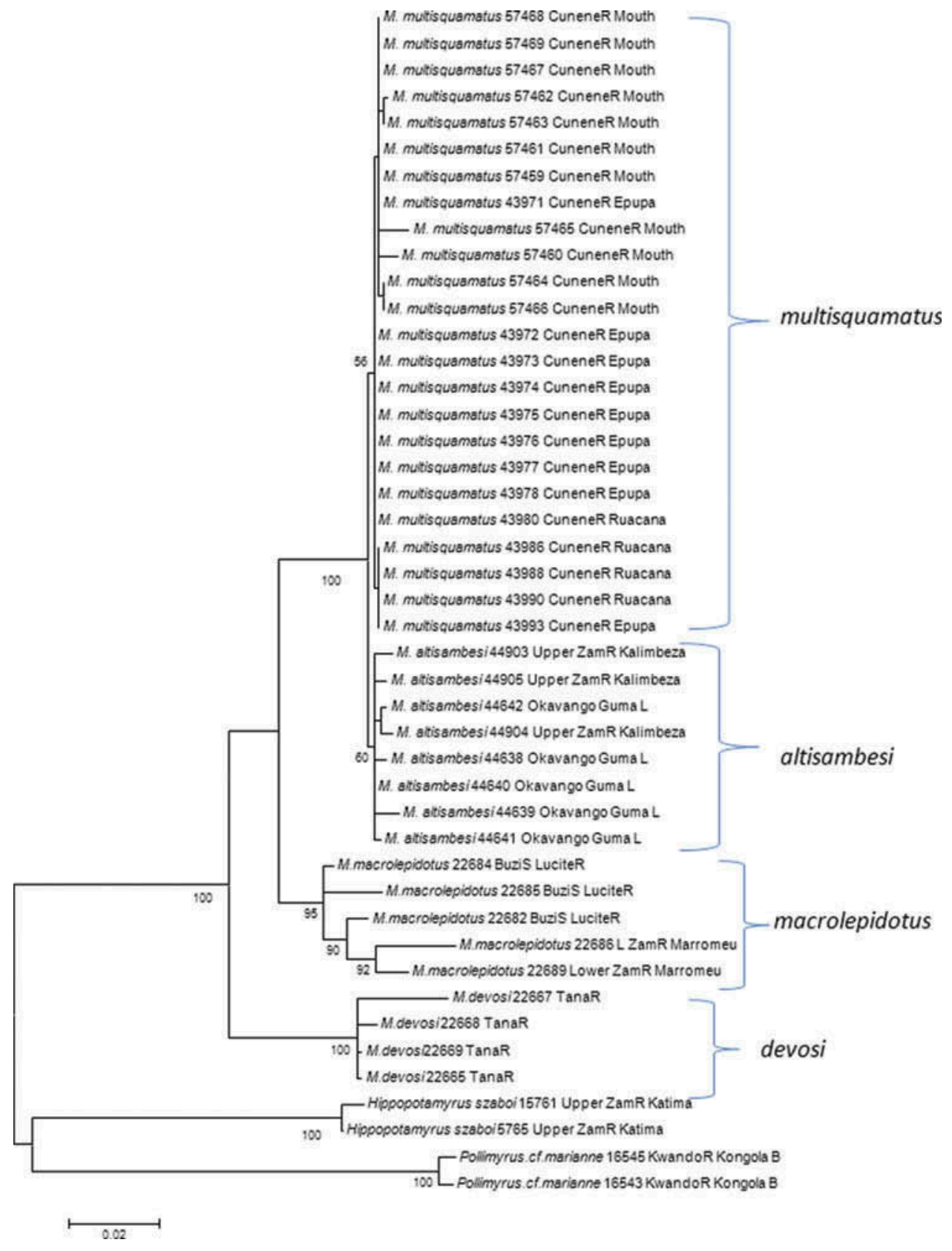

Figure 9. Partial molecular phylogeny of three Marcusenius species from southern Africa. Phylogeny reconstruction by Maximum likelihood is illustrated as a phylogram in which branch length is correlated with genetic distance. Bootstrap values above $50 \%$ are given below the nodes.

Trends towards a bulldog fish body shape to life in stronger currents are present in M. multisquamatus sp. nov. when compared to M. altisambesi from the Upper Zambezi that is a reservoir river with a seasonal floodplain ecology. Among all bulldog fish 
Table 4. Inter-simple-sequence-repeat profile of Marcusenius altisambesi, Marcusenius multisquamatus sp. nov. and Marcusenius macrolepidotus (selection of informative bands, numbers 1 to 13$) ; \mathrm{x}=$ band is present; formatting [bold/italic/bold-italic/clean]: highlighting bands characteristic of species.

\begin{tabular}{|c|c|c|c|c|c|c|c|c|c|c|c|c|c|c|}
\hline Taxon & IPMB ID & 1 & 2 & 3 & 4 & 5 & 6 & 7 & 8 & 9 & 10 & 11 & 12 & 13 \\
\hline \multicolumn{15}{|c|}{ altisambesi } \\
\hline & 44638 & $\mathrm{X}$ & & $\mathrm{X}$ & $\mathrm{X}$ & & $X$ & $\mathrm{X}$ & & $\mathrm{X}$ & & & & \\
\hline & 44639 & & & $X$ & $X$ & & $X$ & $X$ & & $X$ & $X$ & $X$ & & \\
\hline & 44640 & & & $X$ & $\mathrm{X}$ & $X$ & & $X$ & & $X$ & $X$ & $X$ & & \\
\hline & 44641 & & & $\mathrm{X}$ & & $\mathrm{X}$ & & $\mathrm{X}$ & & $\mathrm{X}$ & $\mathrm{X}$ & $\mathrm{X}$ & & \\
\hline & 44642 & & & $\mathrm{X}$ & & & & $\mathrm{X}$ & & $X$ & $X$ & & & \\
\hline & 44903 & & & $X$ & & & & $X$ & & $X$ & $X$ & $X$ & & \\
\hline & 44904 & & & $X$ & & $\mathrm{X}$ & & $\mathrm{X}$ & & $\mathrm{X}$ & $\mathrm{X}$ & $\mathrm{X}$ & & \\
\hline & 44905 & $\mathrm{X}$ & & $\mathrm{X}$ & & & $X$ & $X$ & & $X$ & $X$ & $X$ & & \\
\hline \multicolumn{15}{|c|}{ multisquamatus sp. nov. } \\
\hline & 43971 & $\mathrm{X}$ & $\mathbf{X}$ & $X$ & $\mathrm{X}$ & & & $\mathrm{X}$ & $\mathbf{X}$ & $X$ & $X$ & $X$ & & \\
\hline & 43972 & $\mathrm{X}$ & $\mathbf{X}$ & $X$ & $\mathrm{X}$ & & & $\mathrm{X}$ & & $X$ & $X$ & & & \\
\hline & 43973 & $X$ & $\mathbf{X}$ & $X$ & $\mathrm{X}$ & & & $\mathrm{X}$ & $\mathbf{X}$ & $X$ & $X$ & & & \\
\hline & 43974 & $\mathrm{X}$ & $\mathbf{X}$ & $X$ & $\mathrm{X}$ & & & $X$ & $\mathbf{X}$ & $X$ & $X$ & & & \\
\hline & 43975 & $\mathrm{X}$ & $\mathbf{X}$ & $\mathrm{X}$ & $\mathrm{X}$ & & & $\mathrm{X}$ & $\mathbf{X}$ & $\mathrm{X}$ & $\mathrm{X}$ & $\mathrm{X}$ & & \\
\hline & 43976 & $\mathrm{X}$ & $\mathbf{X}$ & $X$ & $\mathrm{X}$ & & & $\mathrm{X}$ & $\mathbf{X}$ & $X$ & $X$ & & & \\
\hline & 43977 & $X$ & $\mathbf{X}$ & $X$ & $X$ & & & $\mathrm{X}$ & $\mathbf{X}$ & $\mathrm{X}$ & $X$ & & & \\
\hline & 43978 & $X$ & $\mathbf{X}$ & $X$ & $X$ & $X$ & & $X$ & $\mathbf{X}$ & $\mathrm{X}$ & $X$ & & & \\
\hline & 43980 & $X$ & $\mathbf{X}$ & $X$ & $X$ & & & $\mathrm{X}$ & $\mathbf{X}$ & $\mathrm{X}$ & $X$ & & & \\
\hline & 43986 & $X$ & $\mathbf{X}$ & $\mathrm{X}$ & $\mathrm{X}$ & & & $\mathrm{X}$ & $\mathbf{X}$ & $\mathrm{X}$ & $\mathrm{X}$ & $X$ & & \\
\hline & 43988 & $X$ & $\mathbf{X}$ & $X$ & $X$ & $X$ & & $\mathrm{X}$ & $\mathbf{X}$ & $\mathrm{X}$ & $X$ & $X$ & & \\
\hline & 43990 & $X$ & $\mathbf{X}$ & $\mathrm{X}$ & $\mathrm{X}$ & & & $X$ & $\mathbf{X}$ & $\mathrm{X}$ & $X$ & $X$ & & $\boldsymbol{X}$ \\
\hline & 43993 & $X$ & $\mathbf{X}$ & $X$ & $X$ & $X$ & & $X$ & $\mathbf{X}$ & $X$ & $X$ & $X$ & & \\
\hline \multicolumn{15}{|c|}{ macrolepidotus } \\
\hline & 22682 & $\mathrm{X}$ & & $X$ & $\mathrm{X}$ & & & $\mathrm{X}$ & $\mathbf{X}$ & & & & $X$ & $X$ \\
\hline & 22684 & $\mathrm{X}$ & & & & & & & & & & & & $X$ \\
\hline & 22685 & $\mathrm{X}$ & & & & & & & & & & & & $X$ \\
\hline & 22686 & & & & & & & & & & & & $X$ & $X$ \\
\hline & 22689 & & & & & & & & & & & $X$ & & $X$ \\
\hline
\end{tabular}

studied in the present paper, M. multisquamatus sp. nov. features the longest pD (distance dorsal fin origin to end of caudal peduncle) and highest SLS (no. of lateral line scales), that is, the tail section that provides the main thrust is augmented. Also the length of the unpaired fins, LD and LA (dorsal and anal, respectively), forming part of the rear body section, are in the high range compared with the other samples as are $\mathrm{nD}$ and $\mathrm{nA}$ (no. of fin rays for dorsal and anal fins, respectively). These modifications go together with a short head, HL, and, consequently, long snout, LSo. However, body depth, BD, is also in the high range and not low as expected in a truly fusiform fish and strong swimmer.

Whereas in the sample from the neighbouring Okavango $(n=32)$ all specimens encountered had an SPc (no. of scales around caudal peduncle) of exclusively 12, in the Cunene escarpment sample $(n=15)$ the median was 13 (range 12-16), and even greater in the Cunene River mouth sample (median $=14$; range $13-14$; $n=11$ ). 
Together with the high BD (body depth) of M. multisquamatus sp. nov., more typical for a fish of quieter waters, this perhaps indicates that M. multisquamatus sp. nov. is still in the process of adapting to its environment, although its split from the Okavango/Upper Zambezi population is estimated at 690,000 years ago at least.

Aerial photographs show that the area around and above Epupa Falls encounters major seasonal flooding as well as rapid currents. Therefore, the population of bulldog fish between the two major waterfalls, the Ruacana and the Epupa, may not have gone so far in adapting to a purely mountainous river life because of seasonally changing conditions including flooding. As Figure 9 shows, the Cunene samples from mouth, Epupa and Ruacana almost form monophyletic clades, suggesting some sort of reproductive isolation even within the lower Cunene. This seems to be supported by small differences between the escarpment sample $(n=15)$ above $600 \mathrm{~m}$ sea level and the river mouth sample $(n=11)$ : in the latter, mean BD, body depth, was lower (by $1.7 \%), \mathrm{pD}$, distance dorsal fin origin to end of caudal peduncle, even higher (by $1.3 \%$ ), and both median SLS, number of lateral line scales (61 versus 59) and median SPc, no. of scales around caudal peduncle (14 versus 13, respectively) also higher than in the former. All these differences, small as they may appear, are in the direction of an adaptation to a fusiform body shape as seen in strong swimmers, which survive in steep mountain rivers. An example is the South African bulldog fish, M. pongolensis (Fowler, 1934), of fusiform body shape that contrasts with $M$. altisambesi of a deeper bodied shape, as detailed in Kramer et al. (2007). The Cunene river mouth population has gone full way down the escarpment from Epupa Falls at $600 \mathrm{~m}$ altitude to sea level, and is surely one of the most isolated fish populations in the world.

\section{Acknowledgments}

We thank the Ministry of Fisheries and Marine Resources, Namibia, for permission to sample there. We wish to thank two anonymous referees for their critical and helpful comments, as well as the editor. We are grateful to Luis da Costa and Ernst Swartz for organizing the trip to the Cunene and assisting in the capture of fish; Sally Terry for helping getting us started and securing results; Paul Skelton for obtaining and giving permissions and for general support and guidance; F. Herman van der Bank for contributing the specimens from the Cunene River Mouth; Mathilde Awasis (Windhoek) for support with Museum storage space and facilities; James Maclaine, BMNH, for the loan of specimens; Roger Bills (SAIAB) for loaning specimens caught by him; and Dirk Neumann and Uli Schliewen (ZSM) for loaning specimens and support with historical literature. We would also like to thank Ellen Fröhlich for assistance with figures, photos and anatomical measurements; and Birgit Blaul, Lena Dietz, Andreas Lechner, Silvia Förster and Susanne Füssel for measurements. This work was supported by Deutsche Forschungsgemeinschaft grant no. KR 446/12-2 and previous grants.

\section{References}

Balon EK. 1974. Fishes from the edge of Victoria Falls, Africa: demise of a physical barrier for downstream invasions. Copeia. 1974:643-660.

Bell-Cross G, Minshull JL. 1988. The fishes of Zimbabwe. Harare: National Museums and Monuments of Zimbabwe.

Bigorne R. 2003. Mormyridae. In: Paugy D, Lévêque C, Teugels GG, editors. Poissons d'eaux douces et saumâtres de l'Afrique de l'Ouest. The fresh and brackish water fishes of West Africa. Paris: IRD Éditions, Publications scientifiques du Muséum, MRAC; p. 155-222.

Boulenger GA. 1898. A revision of the genera and species of the fishes of the family Mormyridae. Proc Zool Soc Lond. 1898:775-821. 
Boulenger GA. 1905. Descriptions of four new freshwater fishes discovered by Dr. W. J. Ansorge in Angola. Ann Mag Nat Hist (Ser. 7). 15:457-459.

Boulenger GA. 1910. On a large collection of fishes made by Dr. J. W. Ansorge in the Quanza and Bengo Rivers, Angola. Ann Mag Nat Hist (Ser.8). VI:537-560.

Boulenger GA. 1915. Diagnoses de poissons nouveaux. II. Mormyrides, Kneriides, Characinides, Cyprinides, Silurides. Revue de Zoologie Africaine. 4(2):162-171.

Burridge CP, Craw D, Fletcher D, Waters JM. 2008. Geological dates and molecular rates: fish DNA sheds light on time dependency. Mol Biol Evol. 25:624-633.

Cotterill FPD, de Wit MJ. 2011. Geoecodynamics and the Kalahari epeirogeny: linking its genomic record, tree of life and palimpsest into a unified narrative of landscape evolution. S Afr J Geol. 114:493-518.

Eschmeyer WN, editor. Catalog of fishes [Internet]. Electronic version [11 February 2013]. Available from: http://research.calacademy.org/ichthyology/catalog/fishcatmain.asp

Fricke R, Eschmeyer WN. 2012. A guide to Fish Collections in the Catalog of Fishes database. On-line version of 30 March 2012.

Gilchrist JDF, Thompson WW. 1913. The freshwater fishes of South Africa. Annals of the South African Museum (Cape Town, etc). XI(V):321-463.

Gilchrist JDF, Thompson WW. 1917. The freshwater fishes of South Africa. Annals of the South African Museum (Cape Town, etc). XI(VI):465-579.

Gosse J-P. 1984. Mormyriformes. In: Daget J, Gosse J-P, Thys van den Audenaerde DFE, editors. Check-list of the freshwater fishes of Africa. Bondy (France)/Tervuren. Belgium: ORSTOM/MRAC; p. 63-124.

Goudie AS. 2005. The drainage of Africa since the Cretaceous. Geomorphology. 67:437-456.

Hellmich W. 1957. Herpetologische Ergebnisse einer Forschungsreise in Angola. Veröffentlichungen der Zoologischen Staatssammlung München. 5:1-92.

Hopkins CD, Lavoué S, Sullivan JP. 2007. Mormyridae. In: Stiassny MLJ, Teugels GG, Hopkins CD, editors. Poissons d'eaux douces et saumâtres de basse Guinée, ouest de l'Afrique centrale. Vol. 1. Paris: IRD Éditions; p. 220-334.

Jackson PBN. 1961. The fishes of Northern Rhodesia: a check-list of indigenous species. Lusaka: Govt. Printer.

Jubb RA. 1958. A preliminary report on the collections of freshwater fishes made by the Bernard Carp expeditions to the Caprivi Strip, 1949, the lower Sabi river, 1950, and to Barotseland, 1952. Occasional Papers of the National Museums of Southern Rhodesia. 3:177-189.

Koblmüller S, Schliewen UK, Duftner N, Sefc KM. 2008. Age and spread of the haplochromine cichlid fishes in Africa. Mol Phylogenet Evol. 49:153-169.

Kramer B. 1997. A field study of African elephantfish (Mormyridae, Teleostei): electric organ discharges in Marcusenius macrolepidotus (Peters, 1852) and Petrocephalus catostoma (Günther, 1866) as related to sex. J Afr Zool. 111:313-341.

Kramer B. 2013. Differentiation in morphology and electrical signalling in four species of para- and sympatric (Teleostei: Mormyridae) from Côte d'Ivoire, West Africa. Mar Freshw Behav Physiol. http://dx.doi.org/10.1080/10236244.2013.796161

Kramer B, Bills R, Skelton P, Wink M. 2012. A critical revision of the churchill snoutfish, genus Petrocephalus Marcusen, 1854 (Actinopterygii: Teleostei: Mormyridae), from southern and eastern Africa, with the recognition of Petrocephalus tanensis, and the description of five new species. J Nat Hist. 46:2179-2258.

Kramer B, Skelton PH, Van der Bank FH, Wink M. 2007. Allopatric differentiation in the Marcusenius macrolepidotus species complex in southern and eastern Africa: the resurrection of $M$. pongolensis and $M$. angolensis, and the description of two new species (Mormyridae, Teleostei). J Nat Hist. 41:647-708.

Kramer B, Swartz ER. 2010. A new species of Slender Stonebasher within the Hippopotamyrus ansorgii complex from the Cunene River in southern Africa (Teleostei: Mormyriformes). J Nat Hist. 44:2213-2242. 
Kramer B, Van der Bank H, Flint N, Sauer-Gürth H, Wink M. 2003. Evidence for parapatric speciation in the mormyrid fish, Pollimyrus castelnaui (Boulenger, 1911), from the Okavango - Upper Zambezi River Systems: P. marianne sp. nov., defined by electric organ discharges, morphology and genetics. Environ Biol Fish. 67:47-70.

Kramer B, Van der Bank FH, Wink M. 2004. The Hippopotamyrus ansorgii species complex in the Upper Zambezi River System with a description of a new species, H. szaboi (Mormyridae). Zoologica Scripta. 33:1-18.

Kramer B, Westby GWM. 1985. No sex difference in the waveform of the pulse type electric fish, Gnathonemus petersii (Mormyridae). Experientia. 41:1530-1531.

Leviton AE, Gibbs RH, Heal E, Dawson CE. 1985. Standards in herpetology and ichthyology: part I. Standard symbolic codes for institutional resource collections in herpetology and ichthyology. Copeia. 1985:802-832.

Marcusen J. 1864. Die Familie der Mormyren. Eine anatomisch-zoologische Abhandlung. Mém Acad Sci St Pétersburg. 7:1-162.

Matthes H. 1967. The fishes and fisheries of the Ruaha river basin, Tanzania (systematic, ecology, zoogeography, fisheries). East African Freshwater Fisheries Research Organization Occasional Paper [9].

McGarigal K, Cushman S, Stafford S. 2000. Multivariate statistics for wildlife and ecology research. New York: Springer Verlag.

Minshull JL. 2010. What is the significance of Upper Zambezi fish in the Batoka Gorge below Victoria Falls?. Afr J Aquatic Sci. 35:103-106.

Moore AE, Larkin PA. 2001. Drainage evolution in south-central Africa since the breakup of Gondwana. S Afr J Geol. 104:47-68.

Pappenheim P. 1907. Zur Systematik und Variationsstatistik der Mormyriden hauptsächlich aus den deutsch-afrikanischen Schutzgebieten. Nach dem Material des Königlichen Zoologischen Museums zu Berlin. Mitteilungen aus dem Zoologischen Museum in Berlin. 3:339-367.

Peters WCH. 1852. Einige neue Säugethiere und Flussfische aus Mossambique. Monatsber Königl Preuss Akad Wiss Berlin. 1852:273-276.

Poll M, Gosse J-P. 1963. Contribution à l'étude systématique de la faune ichthyologique du Congo Central. Annales Musée Royal de l'Afrique Centrale, Sciences Zoologiques. 116:43-111.

Seegers L. 1996. The fishes of the Lake Rukwa drainage. Annales Sciences Zoologiques (Tervuren). 278:1-407.

Skelton PH. 1993. A complete guide to the freshwater fishes of southern Africa. Halfway House (South Africa): Southern Book Publishers.

Skelton PH. 1994. Diversity and distribution of freshwater fishes in East and Southern Africa. Annales Musée Royal de l'Afrique Centrale, Sciences Zoologiques. 275:95-131.

Skelton P. 2001. A complete guide to the freshwater fishes of southern Africa. Cape Town: Struik Publishers.

Skelton PH, Bruton MN, Merron GS, Van der Waal BCW. 1985. The fishes of the Okavango drainage system in Angola, South West Africa and Botswana: taxonomy and distribution. Ichthyol Bull J.L.B. Smith Inst Ichthyol. 50:1-21.

Stankiewicz J, de Wit MJ. 2006. A proposed drainage evolution model for Central Africa - did the Congo flow east?. J Afr Earth Sci. 44:75-84.

Steindachner F. 1914. Bericht über die ichthyologischen Aufsammlungen der Brüder Adolf und Albin Horn während einer im Sommer 1913 ausgeführten Reise nach Deutsch-Ostafrika. Anzeiger der Kaiserlichen Akademie der Wissenschaften. Mathematisch-Naturwissenschaftliche Klasse. 51:536-538.

Steindachner F. 1916. Bericht über die ichthyologischen Aufsammlungen der Brüder Adolf und Albin Horn während einer im Sommer 1913 ausgeführten Reise nach 
Deutsch-Ostafrika. Denkschriften der Kaiserlichen Akademie der Wissenschaften. Mathematisch-Naturwissenschaftliche Klasse. 92:59-86.

Stieler A. 1910. Hand-atlas. 9th ed. Gotha: Julius Perthes. 239 p.

Tabachnick BG, Fidell LS. 2007. Using multivariate statistics. 5th ed. Boston (MA): Pearson Education.

Tamura K, Peterson D, Peterson N, Stecher G, Nei M, Kumar S. 2011. MEGA5: molecular evolutionary genetics analysis using maximum likelihood, evolutionary distance, and maximum parsimony methods. Mol Biol Evol. 28:2731-2739.

Taverne L. 1971a. Note sur la systématique des poissons Mormyriformes. Le problème des genres Gnathonemus Gill, Marcusenius Gill, Hippopotamyrus Pappenheim, Cyphomyrus Myers et les nouveaux genres Pollimyrus et Brienomyrus. Revue de Zoologie et de Botanique Africaines. 84(1-2):99-110.

Taverne L. 1971b. Ostéologie des genres Marcusenius Gill, Hippopotamyrus Pappenheim, Cyphomyrus Myers, Pollimyrus Taverne et Brienomyrus Taverne (Pisces Mormyriformes). Annales Musée Royal de l'Afrique Centrale, Sciences Zoologiques. 188:x-144 + 3 plates.

Taverne L. 1972. Ostéologie des genres Mormyrus Linné, Mormyrops Müller, Hyperopisus Gill, Isichthys Gill, Myomyrus Boulenger, Stomatorhinus Boulenger et Gymnarchus Cuvier. Considérations générales sur la systématique des poissons de l'ordre des Mormyriformes. Annales Musée Royal de l'Afrique Centrale, Sciences Zoologiques. 200:1-194 + 2 plates.

Thieme ML, Abell R, Stiassny MLJ, Skelton P, Lehner B, Teugels GG, Dinerstein E, Kamdem Toham A, Burgess N, Olson D. 2005. Freshwater ecoregions of Africa and Madagascar: a conservation assessment. Washington, DC: Island Press.

Trewavas E. 1973. A new species of cichlid fishes of rivers Quanza and Bengo, Angola, with a list of the known cichlidae of these rivers and a note on Pseudocrenilabrus natalensis Fowler. Bull Br Mus Nat Hist (Zool). 25:27-37. 


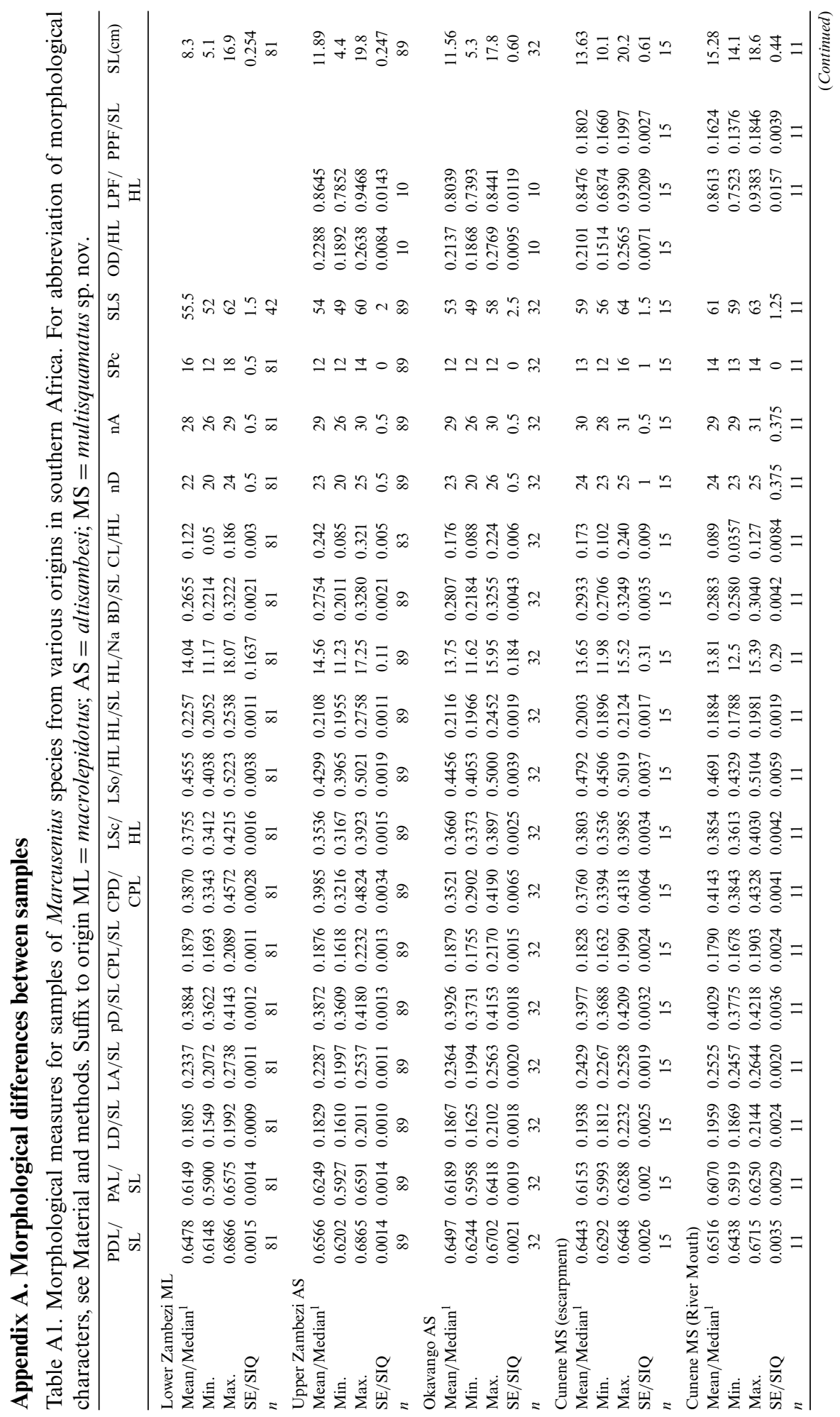




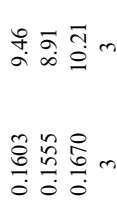

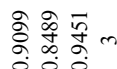

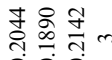

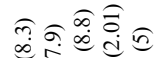

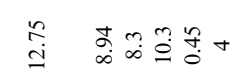

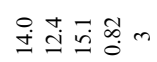

等芦管亭

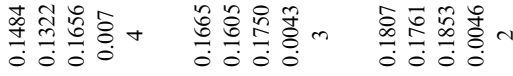

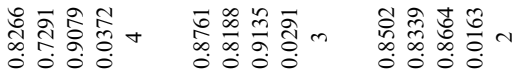

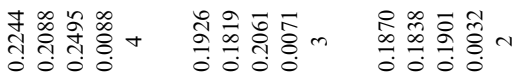

영

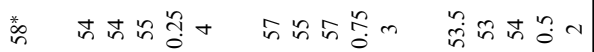

$m \times m$

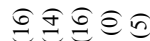

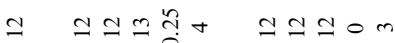

I Ion

ำ ㅇำ

m $\check{m} \bar{m}-ナ$

MNMOM

ำm min

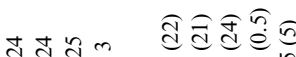

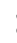

$H_{1} H_{1} H_{1}$

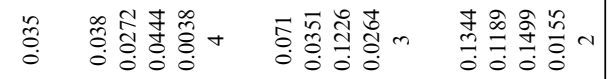

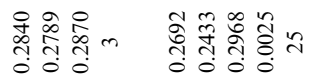

:

히요

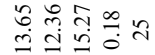

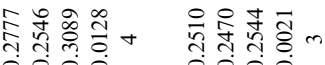

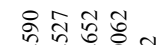

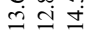

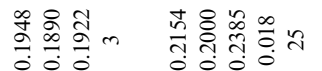

ฉ

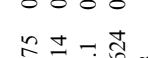

तิ तิ ปึ:

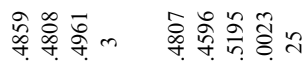

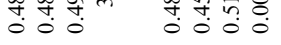

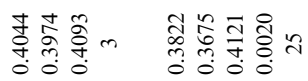

$\because \quad \mathrm{i}= \pm 0$

거에

m:

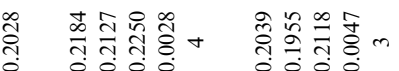

莡

要

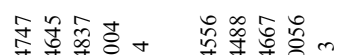

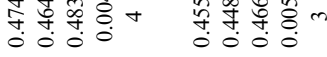

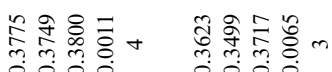

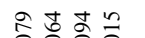

00

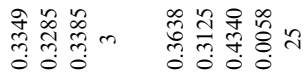

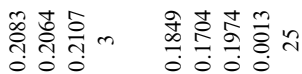

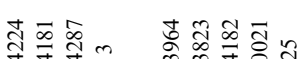

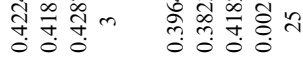

(2)

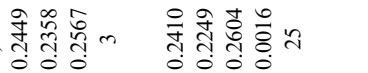

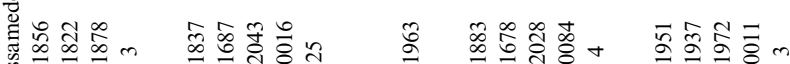

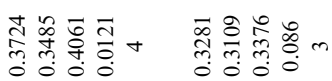

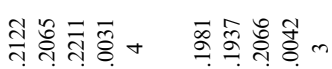

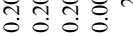

$\sum$

ڤै

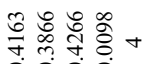

요

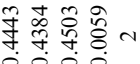

넝ำ

ڤె.

इ0०

矛声

0000

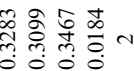

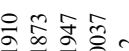
070.0

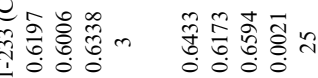

0.0. 0 की

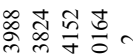

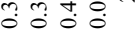

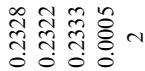

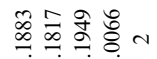

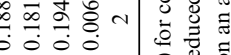

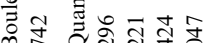

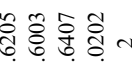

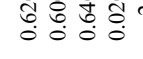

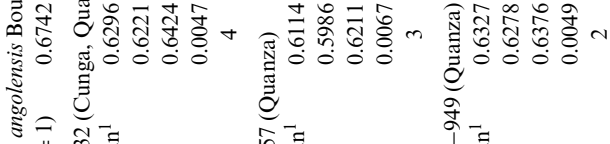

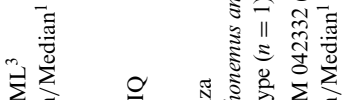

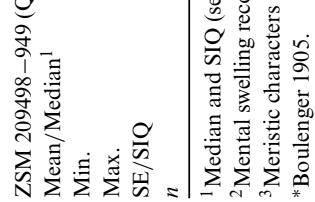




\section{Appendix B. Principal components analysis on morphology}

Table B1. Principal components analysis on correlations for morphological characters of samples of three Marcusenius species from various origins in southern Africa $(n=178)$.

\begin{tabular}{lrrrrrrr}
\hline Eigenvalue & 3.431 & 2.879 & 1.748 & 1.125 & 1.029 & 0.883 & 722 \\
Percent & 24.503 & 20.562 & 12.483 & 8.038 & 7.348 & 6.305 & 5.155 \\
Cum Percent & 24.503 & 45.065 & 57.548 & 65.586 & 72.934 & 79.239 & 84.394 \\
Component loadings & & & & & & & \\
PDL/SL & 0.7258 & -0.4111 & -0.1247 & 0.0884 & 0.1926 & 0.0303 & 0.1708 \\
PAL/SL & 0.8035 & -0.3212 & -0.0839 & 0.0996 & 0.0383 & 0.0713 & 0.0351 \\
LD/SL & 0.1883 & 0.7383 & 0.2736 & -0.3347 & 0.1907 & 0.0096 & 0.1068 \\
LA/SL & 0.0955 & 0.5385 & 0.5871 & 0.1063 & 0.1047 & -0.4082 & -0.1678 \\
pD/SL & -0.5056 & 0.5807 & -0.0589 & -0.3076 & 0.3169 & 0.2523 & 0.1206 \\
CPL/SL & -0.6616 & -0.0873 & -0.4794 & 0.0189 & 0.3098 & 0.2707 & 0.0341 \\
CPD/CPL & 0.6988 & -0.1977 & 0.3895 & -0.1589 & -0.0383 & 0.2553 & 0.1699 \\
LSo/HL & -0.1159 & 0.3976 & -0.4166 & 0.6463 & 0.0726 & -0.3140 & 0.1494 \\
HL/SL & -0.4329 & -0.5239 & 0.1263 & -0.0632 & -0.0697 & -0.2184 & 0.6115 \\
BD/SL & 0.6091 & 0.2509 & -0.0339 & 0.1982 & 0.6400 & -0.0153 & 0.1158 \\
nD & 0.3175 & 0.6415 & -0.3272 & -0.1583 & -0.2018 & 0.0154 & 0.3484 \\
nA & 0.2931 & 0.6153 & -0.1941 & 0.0154 & -0.4986 & -0.0089 & 0.1274 \\
SPc & -0.5166 & -0.0909 & 0.6840 & 0.2013 & 0.0773 & -0.0205 & 0.2419 \\
SLS & -0.0806 & 0.3059 & 0.3424 & 0.5807 & -0.1732 & 0.6005 & 0.0378 \\
\hline Note: Cun & & & & & &
\end{tabular}

Note: Cunene (escarpment specimens, $n=15$ ): M. multisquamatus sp. nov.; Upper Zambezi $(n=89):$ M. altisambesi; Okavango $(n=32)$ : M. altisambesi; Lower Zambezi $(n=42)$ : M. macrolepidotus. 


\section{Corrigendum}

Kramer B, Wink M. 2013. East-west differentiation in the Marcusenius macrolepidotus species complex in Southern Africa: the description of a new species for the lower Cunene River, Namibia (Teleostei: Mormyridae). J Nat Hist. http://dx.doi.org/ 10.1080/00222933.2013.798699

The author(s) have noted that when first published, Figure 5 contained inaccurate information. This has now been corrected, and an updated figure is now present in the article. The corrected article also carries a small number of minor formatting changes. 